\title{
Calibration of FARSITE simulator in northern Iranian forests
}

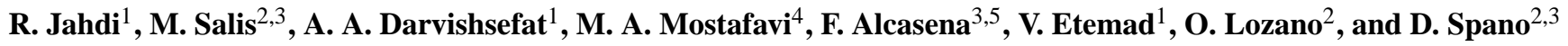 \\ ${ }^{1}$ University of Tehran, Faculty of Natural Resources, P.O. Box 4314, Zobe Ahan Street, 3158777878 Karaj, Iran \\ ${ }^{2}$ University of Sassari, Department of Science for Nature and Environmental Resources (DIPNET), Via Enrico De Nicola 9 , \\ 07100 Sassari, Italy \\ ${ }^{3}$ Euro-Mediterranean Center on Climate Changes (CMCC), IAFENT Division, Via De Nicola 9, 07100 Sassari, Italy \\ ${ }^{4}$ Université Laval, Center for Research in Geomatics (CRG) 1055, Avenue du Séminaire, Pavillon Louis-Jacques-Casault, \\ Québec G1V 0A6, QC, Canada \\ ${ }^{5}$ University of Lleida, Department of Agricultural and Forest Engineering (EAGROF), Alcalde Rovira Roure 191, \\ 25198 Lleida, Spain
}

Correspondence to: $\mathrm{R}$. Jahdi ( $\mathrm{r} \_$jahdi@ut.ac.ir)

Received: 29 August 2014 - Published in Nat. Hazards Earth Syst. Sci. Discuss.: 30 September 2014

Revised: 26 January 2015 - Accepted: 12 February 2015 - Published: 6 March 2015

\begin{abstract}
Wildfire simulators based on empirical or physical models need to be locally calibrated and validated when used under conditions that differ from those where the simulators were originally developed. This study aims to calibrate the FARSITE fire spread model considering a set of recent wildfires that occurred in northern Iranian forests. Sitespecific fuel models in the study areas were selected by sampling the main natural vegetation type complexes and assigning standard fuel models. Overall, simulated fires presented reliable outputs that accurately replicated the observed fire perimeters and behavior. Standard fuel models of Scott and Burgan (2005) afforded better accuracy in the simulated fire perimeters than the standard fuel models of Anderson (1982). The best match between observed and modeled burned areas was observed on herbaceous fuel models. Fire modeling showed a high potential for estimating spatial variability in fire spread and behavior in the study areas. This work represents a first step in the application of fire spread modeling in northern Iran for wildfire risk monitoring and management.
\end{abstract}

\section{Introduction}

Wildfires cause substantial losses of property and human lives in ecosystems in Iran as well as around the world (Keeley and Fotheringham, 2001; Pausas et al., 2008; Banj Shafiei et al., 2010; Bracmort, 2012). Every year, about 6000 ha of forests are affected by fires in Iran (Adab et al., 2013), and al- most $7 \%$ of the area burned is located in the northern Iranian mountainous range (Banj Shafiei et al., 2010). Wildfires in northern Iranian forests are mostly caused by anthropogenic activities, similar to other areas (Syphard et al., 2007; Bird et al., 2008; Romero-Calcerrada et al., 2008; Martinez et al., 2009), and represent the main threat to protected natural areas. The northern Iranian mountainous forests have a very high natural value and correspond to the main habitat for many protected, endangered or endemic animals, such as the Iranian cheetah, the Persian fallow deer, the Persian ground jay, the Caucasus leopard, lynx, brown bear, wild boar, wolf, golden jackal, jungle cat and badger, and plants, such as the Persian ironwood, Caspian beech, the velvet maple and the Caspian locust.

As pointed out by several previous works, wildfire spread is a complex spatial and temporal dynamic process that depends on many factors such as weather, topography, fuel types and fuel moisture content (FMC) (Carvalho et al., 2006; Santoni et al., 2011; Salis et al., 2014a, 2015). The ability to analyze and quantify potential wildfire likelihood, size and intensity is important for an effective wildfire management and proactive emergency response (Gu et al., 2008; Taylor et al., 2013; Ager et al., 2014a). For this reason, several surface fire spread models have been developed under many conditions in different areas around the world, particularly where wildfires are threatening forests, valued resources and human lives (Perry, 1998; Pastor et al., 2003; Sullivan, 2009). These models are implemented for simulating com- 
plex physical-chemical and dynamic processes over large and spatially heterogeneous landscapes and under changing weather and fuel moisture conditions (Finney, 1998; Viegas et al., 1998; Arca et al., 2007, 2009; Forthofer, 2007; Ager et al., 2010, 2012; Salis et al., 2015).

Fire modeling has been extensively applied in the last decades to simulate and characterize fire spread and behavior across diverse types of landscapes (Arca et al., 2007; Duguy et al., 2007; Ager et al., 2011, 2014b; Salis et al., 2013, 2014b). Many wildfire simulators have been developed since the 1990s, such as SIROFIRE (Australia; Coleman and Sullivan, 1996), FARSITE (United States; Finney, 1998), PROMETHEUS (Canada; Prometheus Project Steering Committee, 1999), SPREAD (Portugal; Mendes-Lopes and Aguas, 2000) and ForeFire (France; Balbi et al., 2009). FARSITE is a spatially and temporally explicit fire simulation system developed at the Missoula Fire Sciences Laboratory of the USDA Forest Service and is still currently one of the most used and user-friendly simulators. The simulator, which is a semi-empirical model based on Rothermel's (1972) surface fire spread model, simulates fire growth using Huygens's principle wave propagation and fire intensity using Byram's (1959) equation. FARSITE has been widely calibrated in the US and employed not only to generate spatial maps of fire spread and behavior (Finney and Ryan, 1995; Finney, 1998) but also to evaluate the effects of different silvicultural prescriptions and fuel treatment options on reducing fire hazard (Stephens, 1998; Finney, 2001; Stratton, 2004; LaCroix et al., 2006; Ryu et al., 2007; Schmidt et al., 2008; Cochrane et al., 2012). The use of FARSITE simulator on areas different from those ones where the model was originally developed requires a local calibration and validation (Arca et al., 2007) using observed wildfire data and is the primary step to applying the simulator at larger scales (Ager et al., 2007; Stratton, 2006; Salis et al., 2013). The reliability of FARSITE as a tool for improving wildfire analysis and landscape management options has been reported by several papers in southern Europe (Molina and Castellnou, 2002; Arca et al., 2007; Duguy et al., 2007; Mallinis et al., 2008; Glasa and Halada, 2011), New Zealand, Australia (Opperman et al., 2006) and southeast Asia (Lee et al., 2010). Nevertheless, no studies have been carried out with FARSITE in Iran and the surrounding countries of southwest Asia.

FARSITE requires a set of geospatial input data concerning topography, surface fuel models, canopy characteristics and the physical parameters of the fuel bed, fuel moisture content and weather data. The fire modeling outputs in turn strongly depend on the resolution and reliability of the input data, especially as far as weather data and fuel models are concerned (Arca et al., 2007). Fuel models describe the physical characteristics such as fuel load, heat content and height of live and dead biomass that contribute to the size, intensity and duration of a fire (Scott and Burgan, 2005). Several studies developed photo guides and collections of standard (Anderson, 1982; Scott and Burgan, 2005) and local custom fuel models (Dimitrakopoulos, 2002; Fernandes et al., 2006; Cruz and Fernandes, 2008; Rodríguez y Silva and Molina-Martínez, 2011; Cai et al., 2014; Pierce et al., 2014). Standard fuel models that fit the main local vegetation characteristics can be used as input for fire spread modeling and in combination with custom fuel models when available (Duguy et al., 2007; Arca et al., 2009; Boboulos et al., 2013). Although spatial data availability increased worldwide in recent years (e.g., earthexplorer.usgs.gov), it is still very difficult to generate and update accurate fuel model maps in many regions of the world, like Iran, due to the absence of specific fuel model cartography or the lack of suitable information on mapped vegetation and land use land-cover characteristics (Pettinari et al., 2014).

In this paper, we assessed the capabilities of FARSITE in accurately replicating historical wildfire spread and behavior in northern Iran. We tested two sets of different suitable standard fuel models for the local vegetation types (Anderson, 1982; Scott and Burgan, 2005) in order to identify the ones that better replicate and fit the observed fire events. In addition, we analyzed how fire spread and behavior variables rate of spread (ROS), fireline intensity (FLI) and flame length (FML) - were influenced by standard fuel models. This work represents the first study aiming at calibrating and validating FARSITE in northern forests of Iran. The study can improve our understanding of the potential fire spread and behavior in the southern Caspian forests and help landscape managers for fire management purposes.

\section{Materials and methods}

\subsection{Study area}

This study considered a set of four fires that occurred in the southern Caspian forests of northern Iran, specifically in the Siahkal forest area and in Golestan National Park (GNP; Fig. 1). The south Caspian forests $\left(16481.95 \mathrm{~km}^{2}\right)$ cover about $1.2 \%$ of the whole of Iran (Marvi Mohadjer, 2005) and range from sea level up to $2500 \mathrm{~m}$ a.s.l. (Siadati et al., 2010). The area presents contrasting bioclimatic differences in comparison to the central and southern parts of the country, which are characterized by xeric weather conditions.

The Siahkal forest area is located in northern Iran, occupies $1050 \mathrm{~km}^{2}$ and presents a very high altitudinal range from the lowest areas at 10 to the highest mountains at $2500 \mathrm{~m}$ a.s.l. (Fig. 1). The annual precipitation ranges from $600 \mathrm{~mm}$ in the southern part to $2000 \mathrm{~mm}$ in the northern and highest mountains, and most of the annual rainfall occurs in autumn. Air relative humidity exceeding $80 \%$ is responsible for frequent fogs at the highest altitudes. The average annual temperature is 16 and $25^{\circ} \mathrm{C}$ in summer. Average minimum temperatures of the coldest month are usually over $0^{\circ} \mathrm{C}$ (Akhani et al., 2010). The Siahkal forest area is lo- 


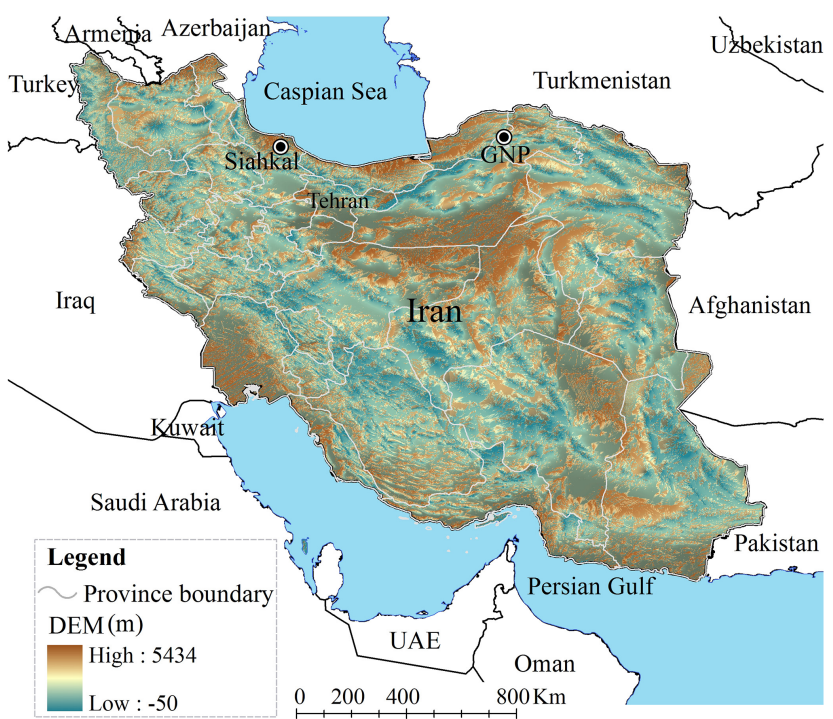

Figure 1. Location of the Siahkal forest area and Golestan National Park (GNP) in northern Iran.

cated in the long, narrow vegetation belt on the northward slopes of the Alborz Mountains and constitutes the majority of the Eurosiberian flora in Iran (Djamali et al., 2009). The highest proportion of the Siahkal area is covered by forests $(\sim 46 \%)$ that are dominated by temperate broad-leaved deciduous trees such as various thermophilous Tertiary relict species (e.g., Zelkova carpinifolia, Parrotia persica, Pterocarya fraxinifolia, Quercus castaneifolia) and Asian subtropical trees in some cases (e.g., Diospyros lotus, Gleditsia caspica, Danae racemosa, Albizia julibrissin) (Table 1; Akhani, 1998; Akhani and Ziegler, 2002; Leestmans, 2005; Leroy and Arpe, 2007).

The Golestan National Park is situated in northeast Iran and covers about $920 \mathrm{~km}^{2}$ of land (Fig. 1). The National Park is located in a transitional position between the sub-humid south Caspian region and the semi-arid zones of the central and east-central Iranian Plateau. The GNP ranges from 450 to $2400 \mathrm{~m}$ a.s.l. The wet air masses from the Caspian Sea are blocked by the high mountain ranges, which create particular microclimatic conditions, with annual precipitation ranging from $150 \mathrm{~mm}$ in the southeast to more than $1000 \mathrm{~mm}$ in some central parts of the GNP (Akhani, 1998). The mean annual temperature is $11.5-17.5^{\circ} \mathrm{C}$ and the mean summer temperature is $28^{\circ} \mathrm{C}$ (Akhani, 1998). The park exhibits a diverse mosaic of vegetation units, including the Hyrcanian lowto high-altitude mesophytic forests, shrublands, open and closed scrub sometimes mixed with $\mathrm{C} 4$ grasslands, Juniperus woodlands, mountain steppes and meadows, Artemisia and Artemisia-Stipa steppes and different transitional and halophilous communities (Table 1; Akhani, 1998; Akhani and Ziegler, 2002).

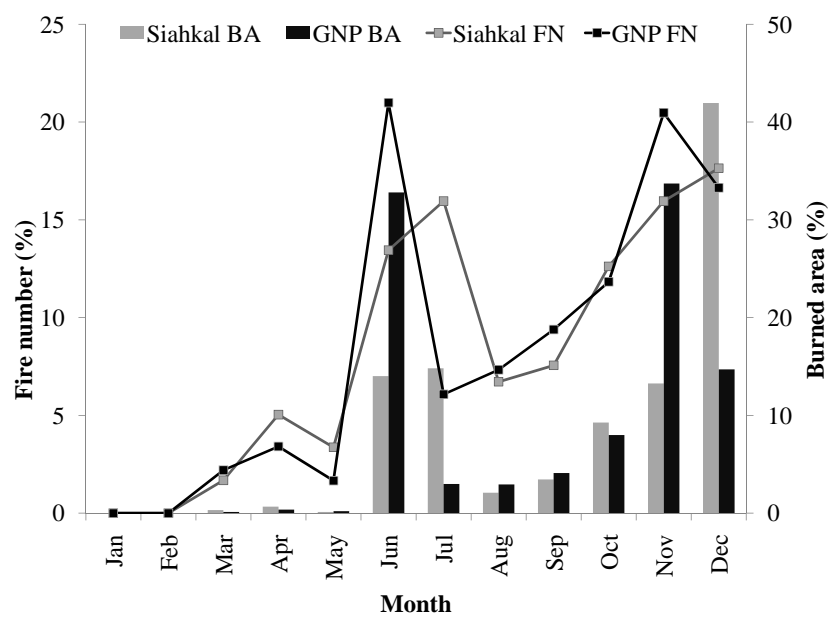

Figure 2. Monthly mean fire number (FN) and burned area (BA) in Siahkal forest area and GNP (2000-2011; data from Department of Forestry, Natural Resources Office, Guilan, and Department of Environment, Golestan, Iran, personal communication, 2011, 2012).

\subsection{Wildfire history}

In the period 2000-2011, northern Iran experienced annually on average about $\sim 400$ fires that burned around $\sim 2000$ ha. Large and extreme fires in the study areas are commonly linked to drought conditions, heat waves, strong winds and fine dead fuel accumulation (Mirdeylami et al., 2014). As many as $90 \%$ of the fires in the northern Iran and study areas are caused by people (Sarkargar Ardakani, 2007; Zarekar et al., 2013; Mirdeylami et al., 2014). Fires in northern Iran commonly occur during the short drought season in autumn, characterized by hot and dry winds that desiccate the forest understory. These conditions mostly lead to low-intensity surface fires that rarely exceed $0.3 \mathrm{~m}$ flame height (Adel et al., 2012).

Wildfires in the GNP, as well as in the Siahkal forests, are distributed from June to December, with two peaks in the number of fires and area burned in June-July and November-December (Fig. 2). Although observed annual fires and burned area in the GNP and the Siahkal forests present high interannual variability during the period 2000 2011, the hardest wildfire campaigns correspond to the latest years and especially to 2010 (Fig. 3). During the period 2000-2011, the Siahkal area experienced on average about $\sim 13$ fires per year and about $\sim 60$ ha burned (Department of Forestry, Natural Resources Office, Guilan, Iran; Fig. 3). Approximately $85 \%$ of the fires in Siahkal burned less than 10 ha; a small number of fires (about $15 \%$ ) is responsible for half of the area burned (Fig. 4) and no fires larger than 100 ha were observed in the studied period. In the GNP during the period 2000-2011, 12 fires per year have been recorded on average, with $\sim 200$ ha burned (Fig. 2). In this area, the largest fires (>100 ha) accounted for about $15 \%$ of the fires and were responsible for almost $75 \%$ of the total area burned 
Table 1. Case study description.

\begin{tabular}{|c|c|c|c|c|}
\hline \multirow{2}{*}{$\begin{array}{l}\text { Site } \\
\text { Wildfire }\end{array}$} & \multicolumn{2}{|c|}{ Siahkal } & \multicolumn{2}{|c|}{ Golestan National Park } \\
\hline & Toshi & Malekroud & YekeBermagh & Gharangi \\
\hline $\begin{array}{l}\text { Latitude of the ignition } \\
\text { point }\end{array}$ & $37^{\circ} 11^{\prime}$ & $37^{\circ} 03^{\prime}$ & $37^{\circ} 22^{\prime}$ & $37^{\circ} 21^{\prime}$ \\
\hline $\begin{array}{l}\text { Longitude of the ignition } \\
\text { point }\end{array}$ & $49^{\circ} 88^{\prime}$ & $49^{\circ} 84^{\prime}$ & $56^{\circ} 03^{\prime}$ & $56^{\circ} 02^{\prime}$ \\
\hline $\begin{array}{l}\text { Elevation }(m) \text { of the } \\
\text { ignition point }\end{array}$ & 210 & 120 & 2080 & 1370 \\
\hline $\begin{array}{l}\text { Main fuel types affected } \\
\text { by the fire }\end{array}$ & $\begin{array}{l}\text { grasslands, grass-shrublands } \\
\text { and timber understory }\end{array}$ & timber litter & $\begin{array}{l}\text { grasslands and } \\
\text { grass-shrublands }\end{array}$ & $\begin{array}{l}\text { timber understory and timber } \\
\text { litter }\end{array}$ \\
\hline Dominant plant species & $\begin{array}{l}\text { Carpinus betulus L., Quercus } \\
\text { castaneifolia } \text { C. A. Mey., } \\
\text { Alnus subcordata } \text { C. A. Mey., } \\
\text { Parrotia persica } \text { C. A. Mey., } \\
\text { Acer insigne var. velutinum } \\
\text { Boiss., Asperula odorata L., } \\
\text { Euphorbia helioscopia } \text { L., } \\
\text { Ilex aquifolium L. }\end{array}$ & $\begin{array}{l}\text { Acer insigne var. velutinum } \\
\text { Boiss., Quercus castaneifolia } \\
\text { C. A. Mey., Fagus orientalis } \\
\text { C. A. Mey., Populus caspica } \\
\text { C. A. Mey., Tilia begonifo- } \\
\text { lia Stev., Pyrus communis L., } \\
\text { Buxus hyrcana Pojark., } \\
\text { Mespilus germanica L., } \\
\text { Smilax excelsa L., Hypricum } \\
\text { androsenum L. }\end{array}$ & $\begin{array}{l}\text { Festuca drymeia } \\
\text { Mert. \& Koch., Artemisia } \\
\text { sieberi Besser., Astragalus } \\
\text { jolderensis B. Fedtsch., } \\
\text { Poa bulbosa } \text { L., Thymus } \\
\text { kotschyanus Boiss. \& Hohen., } \\
\text { Stipa holosericea Trin., } \\
\text { Juniperus excelsa M. Bieb., } \\
\text { Juniperus communis L. }\end{array}$ & $\begin{array}{l}\text { Quercus castaneifolia } \\
\text { C. A. Mey., Carpinus } \\
\text { betulus L., Carpinus orien- } \\
\text { talis Mill., Acer cappadocicum } \\
\text { Gled., Mespilus germanica L., } \\
\text { Euphorbia amygdaloides L., } \\
\text { Viola alba Besser., Primula } \\
\text { heterochroma Stapf., Galium } \\
\text { odoratum (L.) Scop. }\end{array}$ \\
\hline $\begin{array}{l}\text { Fire ignition } \\
\text { (date and hour in LT) }\end{array}$ & 14 August 2010 (16:00) & 17 December 2010 (17:00) & 15 July 2011 (11:00) & 28 March 2011 (14:00) \\
\hline $\begin{array}{l}\text { Fire extinguishment } \\
\text { (date and hour) }\end{array}$ & 15 August $2010(17: 00)$ & 18 December 2010 (08:00) & 15 July 2011 (21:00) & 28 March 2011 (21:00) \\
\hline Burned area (ha) & 34.18 & 24.05 & 58.06 & 10.04 \\
\hline
\end{tabular}

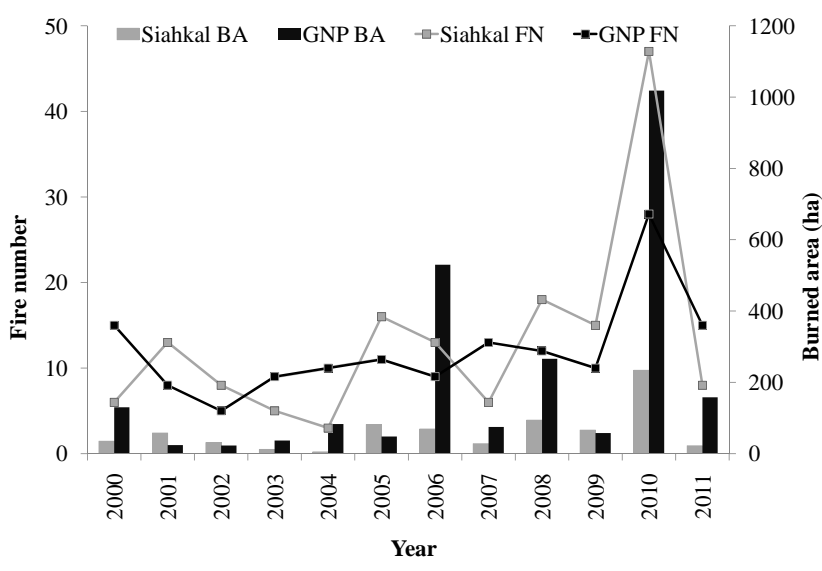

Figure 3. Fire number (FN) and burned area (BA) in Siahkal forest area and GNP (2000-2011; data from Department of Forestry, Natural Resources Office, Guilan, and Department of Environment, Golestan, Iran, personal communication, 2011, 2012).

(Department of Environment, Golestan, Iran; Fig. 4). The largest wildfire in the GNP (Cheshme-Sardar fire event) was observed on 15 November 2010 and burned an area of about 900 ha.

\subsection{Case studies}

Four wildfires that affected the study areas during the 2010 and 2011 fire seasons were selected as case studies: Toshi

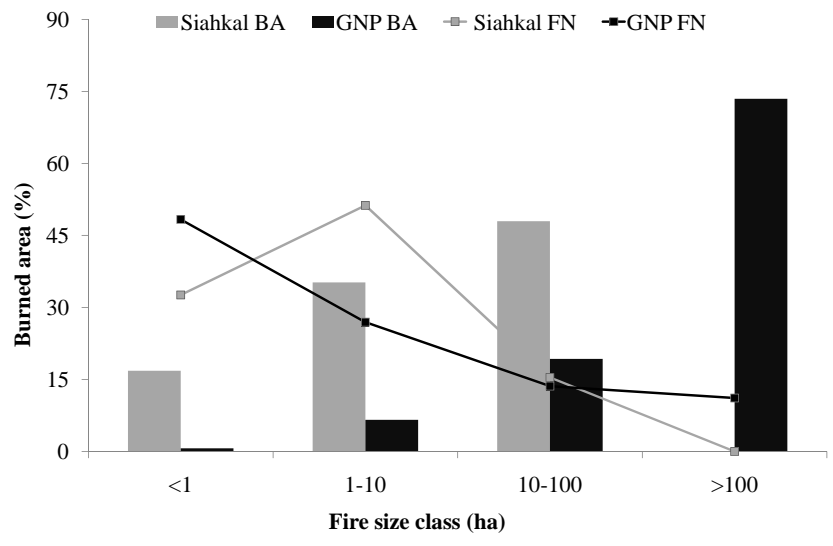

Figure 4. Historical relationship between fire size categories and percentage of fire number (FN) and burned area (BA) in Siahkal forest area and GNP (2000-2011; data from Department of Forestry, Natural Resources Office, Guilan, and Department of Environment, Golestan, Iran, personal communication, 2011, 2012).

and Malekroud fires in Siahkal forest and YekeBermagh and Gharangi fires in the Golestan National Park (Fig. 1). The exact location, main types and dominant species of vegetation together with fire data for the different case studies are summarized in the Table 1. For all case studies, ignition location coordinates were determined from fire reports (Department of Forestry, Natural Resources Office, Guilan, and Department of Environment, Golestan, Iran, personal com- 
munication, 2011, 2012) and interviews with forest rangers, firefighters and park managers, and burned area perimeters were recorded after the fire events using the Global Positioning System (GPS).

The Toshi wildfire occurred near the village of Toshi (lat $37^{\circ} 11^{\prime} \mathrm{N}$, long $49^{\circ} 88^{\prime} \mathrm{E}$ ) in August 2010, and the $25 \mathrm{~h}$ fire event burned 34 ha (Fig. 5; Table 1) of mixed dense woodland $(\sim 16.4$ ha), grasslands $(\sim 13.4$ ha $)$ and grass-shrublands $(\sim$ $4.7 \mathrm{ha})$. The ignition point was located near a steep slope in an agricultural area (Fig. 5). The weather was characterized by a maximum temperature of $35^{\circ} \mathrm{C}$, average relative humidity of $50 \%$ and northeast winds (Table 2). The fire spread towards southeast, driven by the wind and the topographic conditions.

The Malekroud wildfire occurred near the town of Malekroud (lat $37^{\circ} 03^{\prime} \mathrm{N}$, long $49^{\circ} 84^{\prime} \mathrm{E}$ ) in December 2010 and burned approximately 24 ha covered by heterogeneous structural characteristic mature forest in a low-elevation area (Fig. 5; Table 1). The fire started near a road along the southern border of the fire perimeter. It was extinguished by the forest firefighters after $17 \mathrm{~h}$ near a road along the northern border of the fire perimeter (Fig. 5). The day was characterized by a moderate maximum temperature $\left(\sim 25^{\circ} \mathrm{C}\right)$, average relative humidity of $58 \%$ and southern winds. The fire was driven northward by the mild slope and the wind.

The YekeBermagh wildfire occurred in the southern part of the Golestan National Park (lat $37^{\circ} 22^{\prime} \mathrm{N}$, long $56^{\circ} 03^{\prime} \mathrm{E}$ ) in July 2011 (Fig. 5; Table 1). The northern part of the YekeBermagh area is characterized by a flat topography, while the southern part has a more complex and steep terrain with high spatial and temporal variability in wind speed and direction. Most of the 60 ha burned was covered by grasslands. Juniperus woodlands and grass-shrublands composed by montane Juniperus excelsa in steep slopes and subalpine Juniperus communis on exposed high slopes (Akhani, 1998) were also affected by the fire. The day of the fire the weather was hot $\left(31^{\circ} \mathrm{C}\right.$ maximum temperature) and dry $(21 \%$ relative humidity). Fire spread was driven by the topography and the southwestern winds.

The Gharangi wildfire occurred in March 2011, in the southern part of the Golestan National Park (lat $37^{\circ} 21^{\prime} \mathrm{N}$, long $56^{\circ} 02^{\prime} \mathrm{E}$ ), and burned about 10 ha (Fig. 5; Table 1) of dense-mixed woodland. The area presents a mountainous orography with an altitude range between 1200 and $2160 \mathrm{~m}$ a.s.l. The fire weather was mild, with a maximum air temperature of $17^{\circ} \mathrm{C}$ and average relative humidity of $49 \%$. The fire spread towards the north and northeast, driven by southwest winds. The fire intensity was low due to the shielding effect of the dense and closed canopy.

\subsection{Fuel mapping and fuel model assignments}

Fuel model and canopy characteristic maps for the study areas were produced by field sampling on the vegetation complexes existing on the 1:25000 land-cover maps of 2004

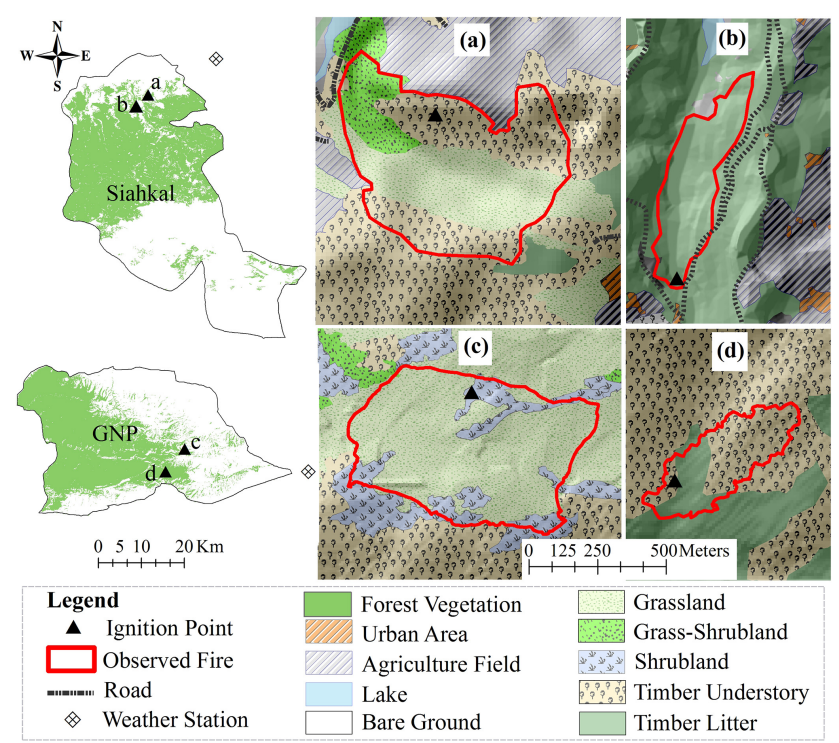

Figure 5. Fuel type maps of the sites where the selected fire events occurred: (a) Toshi and (b) Malekroud in Siahkal forest area; (c) YekeBermagh and (d) Gharangi in GNP. The nearest weather stations to the fire events are presented on the map.

(Department of Forestry, Natural Resources Office, Guilan, and Department of Environment, Golestan, Iran) due to the lack of information on forest and shrubs cover types that could allow standard fuel model assignment. Furthermore, with the georeferenced data derived from field sampling in the study areas we generated fuel model maps and photo guides, improving the initial $1: 25000$ land-cover maps and creating finer-scale vegetation layers. The field samplings were conducted following the line-intercept sampling (Marshall et al., 2000, 2003) method, with the objective of measuring the surface fuel model parameters and canopy characteristics.

On the whole, according to the topography in the study areas and the vegetation types, 21 line transects with a distance of $150 \mathrm{~m}$ in Siahkal forests and 25 line transects with a distance of $100 \mathrm{~m}$ in the GNP were used to georeference 188 and 250 sampling plots, respectively (Table 3 ). Considering the spatial distribution and the coverage degree for the different species within the different vegetation types, $1 \mathrm{~m} \times 1 \mathrm{~m}$ square sampling plots were used for herbaceous fuel types and $10 \mathrm{~m} \times 10 \mathrm{~m}$ square sampling plots for shrubby and forested vegetation types. We measured species composition, fuel-bed depth, litter type (conifer or broadleaf), herbaceous cover, shrub cover and canopy cover (Table 3 ). Visual estimations were used to assign a canopy cover class $(<1,1-$ $5,6-10,11-25,26-50,51-75$ and $76-100 \%)$ in every plot. We also produced a photo guide for main fuel models types (Fig. 6)

In this study, standard fuel models (Anderson, 1982; Scott and Burgan 2005) were assigned to the existing vegetation 
Table 2. Weather conditions observed during the wildfire days in the closest weather stations.

\begin{tabular}{|c|c|c|c|c|}
\hline \multirow{2}{*}{$\begin{array}{l}\text { Site } \\
\text { Wildfires }\end{array}$} & \multicolumn{2}{|c|}{ Siahkal $^{1}$} & \multicolumn{2}{|c|}{ Golestan National Park ${ }^{2}$} \\
\hline & Toshi & Malekroud & YekeBermagh & Gharangi \\
\hline Maximum temperature $\left({ }^{\circ} \mathrm{C}\right)$ & 35 & 25 & 31 & 17 \\
\hline Minimum temperature $\left({ }^{\circ} \mathrm{C}\right)$ & 20 & 7 & 14 & 5 \\
\hline Precipitation $(\mathrm{mm})$ & 0 & 0 & 0 & 0 \\
\hline Maximum wind speed $\left(\mathrm{km} \mathrm{h}^{-1}\right)$ & 28.8 & 32.4 & 25.2 & 18.0 \\
\hline Average wind speed $\left(\mathrm{km} \mathrm{h}^{-1}\right)$ & 21.6 & 23.4 & 21.6 & 14.4 \\
\hline Average wind direction & $\mathrm{NE}$ & $\mathrm{S}$ & SW & SW \\
\hline Average air relative humidity (\%) & 50 & 58 & 21 & 49 \\
\hline
\end{tabular}

Table 3. Vegetation types and respective fuel models and fuel moisture parameters used in FARSITE simulations.

\begin{tabular}{|c|c|c|c|c|c|c|c|c|c|c|c|c|c|c|}
\hline \multirow[b]{3}{*}{ Wildfire } & \multirow[b]{3}{*}{$\begin{array}{l}\text { Vegetation } \\
\text { type }\end{array}$} & \multirow[b]{3}{*}{$\begin{array}{l}\text { Number of } \\
\text { sample } \\
\text { plots }\end{array}$} & \multirow{2}{*}{\multicolumn{4}{|c|}{ Surface fuel model data }} & \multirow[b]{3}{*}{$\begin{array}{c}\text { Canopy } \\
\text { cover } \\
(\%)\end{array}$} & \multirow{2}{*}{\multicolumn{2}{|c|}{$\begin{array}{l}\text { Assigned fuel } \\
\text { models }\end{array}$}} & \multicolumn{5}{|c|}{$\mathrm{FMC}^{1}(\%)$} \\
\hline & & & & & & & & & & \multicolumn{3}{|c|}{ Dead fuel $(\%)$} & \multicolumn{2}{|c|}{ Live fuel $(\%)$} \\
\hline & & & $\begin{array}{l}\text { Fuel bed } \\
\text { depth } \\
(\mathrm{cm})\end{array}$ & $\begin{array}{l}\text { Litter } \\
\text { type }\end{array}$ & $\begin{array}{c}\text { Herbaceous } \\
\text { cover } \\
(\%)\end{array}$ & $\begin{array}{c}\text { Shrub } \\
\text { cover } \\
(\%)\end{array}$ & & $\begin{array}{l}\text { Scott and } \\
\text { Burgan } \\
(2005)\end{array}$ & $\begin{array}{c}\text { Anderson } \\
\text { (1982) }\end{array}$ & $1 \mathrm{~h}^{2}$ & $10 h^{3}$ & $100 h^{4}$ & $\mathrm{LH}^{5}$ & $\mathrm{LW}^{6}$ \\
\hline \multirow{3}{*}{ Toshi } & grassland & 55 & 65.5 & - & 75 & - & 30 & $\begin{array}{l}\text { GR3, } \\
\text { GR5, } \\
\text { GR6 }\end{array}$ & FM3 & 11 & 12 & 14 & 0 & 0 \\
\hline & $\begin{array}{c}\text { grass- } \\
\text { shrubland }\end{array}$ & 27 & 82.0 & broadleaf & 40 & 40 & 20 & $\begin{array}{l}\text { GS3, } \\
\text { GS4 }\end{array}$ & $\begin{array}{l}\text { FM5, } \\
\text { FM6 }\end{array}$ & 11 & 12 & 14 & 0 & 70 \\
\hline & $\begin{array}{c}\text { natural } \\
\text { mixed } \\
\text { forest }\end{array}$ & 41 & 4.5 & broadleaf & 25 & 10 & 80 & $\begin{array}{l}\text { TU2, } \\
\text { TU3 }\end{array}$ & $\begin{array}{l}\text { FM9, } \\
\text { FM10 }\end{array}$ & 11 & 12 & 14 & 0 & 100 \\
\hline Malekroud & $\begin{array}{l}\text { mixed and } \\
\text { pure } \\
\text { plantation }\end{array}$ & 65 & 5.0 & $\begin{array}{l}\text { conifer } \\
\text { and } \\
\text { broadleaf }\end{array}$ & 15 & 10 & 75 & $\begin{array}{l}\text { TL2, } \\
\text { TL6, } \\
\text { TL8, } \\
\text { TL9 }\end{array}$ & $\begin{array}{l}\text { FM9, } \\
\text { FM10 }\end{array}$ & 14 & 15 & 17 & 50 & 100 \\
\hline \multirow{3}{*}{ YekeBermagh } & grassland & 130 & 45.0 & - & 85 & - & 50 & $\begin{array}{l}\text { GR4, } \\
\text { GR7 }\end{array}$ & FM3 & 5 & 6 & 8 & 0 & 0 \\
\hline & $\begin{array}{c}\text { grass- } \\
\text { shrubland }\end{array}$ & 38 & 54.5 & conifer & 30 & 40 & 10 & $\begin{array}{l}\text { GS1, } \\
\text { GS2 }\end{array}$ & $\begin{array}{l}\text { FM5, } \\
\text { FM6 }\end{array}$ & 5 & 6 & 8 & 0 & 60 \\
\hline & shrubland & 35 & 75.5 & conifer & 35 & 50 & 45 & $\begin{array}{l}\text { SH1, } \\
\text { SH2 }\end{array}$ & $\begin{array}{l}\text { FM5, } \\
\text { FM6 }\end{array}$ & 5 & 6 & 8 & 0 & 70 \\
\hline \multirow[t]{2}{*}{ Gharangi } & $\begin{array}{c}\text { natural } \\
\text { mixed } \\
\text { forest }\end{array}$ & 27 & 3.5 & broadleaf & 10 & 5 & 80 & $\begin{array}{l}\text { TU1, } \\
\text { TU5 }\end{array}$ & $\begin{array}{l}\text { FM8, } \\
\text { FM10 }\end{array}$ & 13 & 14 & 16 & 75 & 100 \\
\hline & $\begin{array}{l}\text { natural } \\
\text { pure } \\
\text { forest }\end{array}$ & 20 & 4.0 & broadleaf & 15 & 5 & 75 & $\begin{array}{l}\text { TL2, } \\
\text { TL6, } \\
\text { TL9 }\end{array}$ & $\begin{array}{l}\text { FM9, } \\
\text { FM10 }\end{array}$ & 13 & 14 & 16 & 75 & 100 \\
\hline
\end{tabular}

${ }^{1}$ Fuel moisture content; ${ }^{2} 0-0.6 \mathrm{~cm}$ diameter particle size class; ${ }^{3} 0.6-2.5 \mathrm{~cm}$ diameter particle size class; ${ }^{4} 2.5-7.6 \mathrm{~cm}$ diameter particle size class; ${ }^{5}$ live herbaceous; ${ }^{6}$ live woody.

and land use land-cover types based on their similarities in structural characteristics (Figs. 5, 6; Table 3). The grassdominated standard fuel models used were GR3, GR4, GR5, GR6, GR7 and FM3. GS1, GS2, GS3, GS4, FM5 and FM6 fuel models were considered for the vegetation, presenting a mixture of grass and shrub components. SH1, SH2, FM5 and FM6 fuel models were assigned to areas with sparse grassland among shrubby patches covering at least the $50 \%$ of the surface. In forested areas with grass-shrub and litter mixed understory, TU1, TU2, TU3, TU5, FM8, FM9 and FM10 fuel models were used, whereas TL2, TL6, TL8 and TL9 were used for woody fuels beneath forest canopies. FM9 and FM10 fuel models were assigned to the timber litter, hardwood litter and litter and understory areas. Non-burnable (NB) fuel models were assigned for roads, buildings, urban areas, ploughed agricultural lands, water bodies and bare ground; in that case the geospatial information was gathered from the $1: 25000$ digital topographic maps (National Cartographic Center of Iran). 
(a)

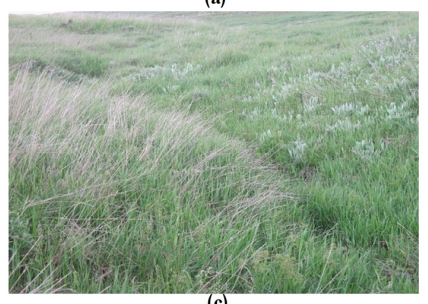

(c)
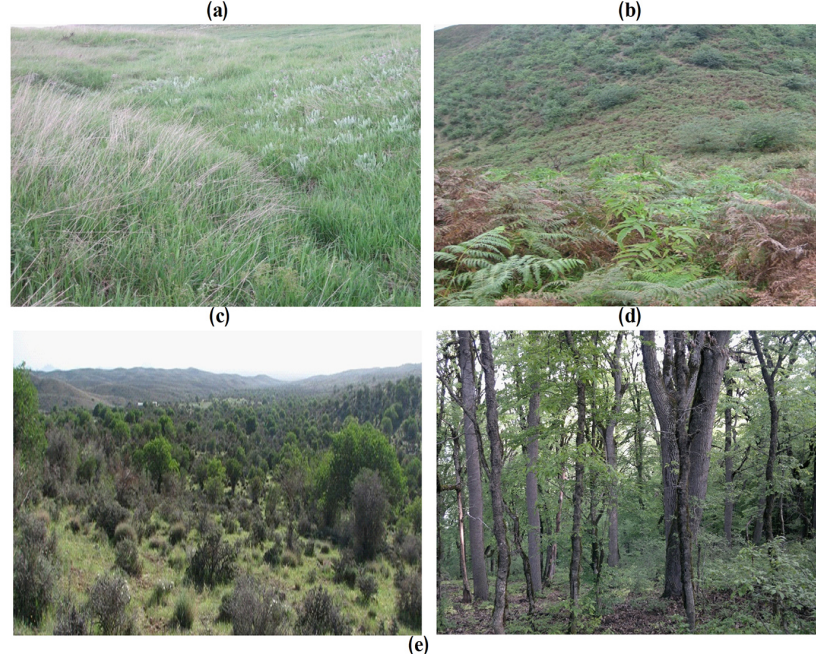

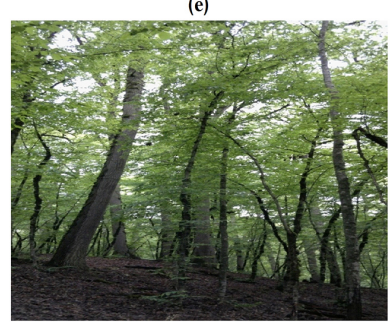

Figure 6. Photo guide of the main fuel types of the study areas: (a) grasslands (GR3, GR4, GR5, GR6, GR7 and FM3 fuel models), (b) grass-shrublands (GS1, GS2, GS3 and GS4 fuel models), (c) shrublands (SH1, SH2, FM5 and FM6 fuel models), (d) natural mixed forest (TU1, TU2, TU3, TU5, FM8, FM9 and FM10 fuel models) and (e) natural pure forest (TL2, TL6, TL8, TL9, FM9 and FM10 fuel models).

\subsection{Input data for fire simulations}

Fire spread simulation systems require spatial grids of topography (slope, aspect and elevation), surface fuels (fuel model) and fuels canopy characteristics (i.e., stand height, crown base height, crown bulk density, canopy cover) as basic inputs for the simulations. These data layers were assembled in a landscape file with $10 \mathrm{~m}$ resolution. Topography layers were derived from the digital elevation model $(10 \mathrm{~m}$ resolution; National Cartographic Center of Iran, NCC) for each study area. As previously described, surface fuel layers were prepared based on land-cover maps and field sampling.

Weather data of the day of the fire, corresponding to hourly air temperature, relative humidity, rainfall, wind speed and wind direction, were collected from the weather stations nearest to the wildfire case studies (Fig. 5 and Table 2).

Initial fuel moisture content for the 1,10 and $100 \mathrm{~h}$ dead fuels (Table 3) was determined following the methodology proposed by Rothermel (1983; Table A1). With this method, we estimated the fine dead FMC for each case study, and then we derived 10 and $100 \mathrm{~h}$ dead moisture by adding 2 and $4 \%$, respectively, to the $1 \mathrm{~h}$ dead FMC (Hardison, 2003). The live

herbaceous and woody FMC values (Table 3 ) were estimated from literature data (Arca et al., 2007; Sağlam et al., 2008; Chuvieco et al., 2011) and mostly from field observations.

\subsection{FARSITE simulations}

Fire simulations were run at $10 \mathrm{~m}$ of resolution using different combinations of standard fuel models (Anderson, 1982; Scott and Burgan, 2005) for the main fuel types (i.e., grasslands, grass-shrublands, shrublands, timber understory and timber litter) affected during wildfire events (Table 4). For all simulations and fuel models, the adjustment factor for the fire spread rate was set at 1.0. Suppression activities were not considered in the simulations due to the lack of information, as well as spot and crown fires, since both were not observed in the case studies presented in this paper. Ignition location and fire spread duration used as inputs for each case study are provided in Table 1. Vector files of the simulated fire perimeters and gridded data of simulated rate of spread $\left(\mathrm{m} \mathrm{min}^{-1}\right)$, fireline intensity $\left(\mathrm{kW} \mathrm{m}^{-1}\right)$ and flame length $(\mathrm{m})$ were exported and analyzed in GIS environment.

\subsection{Statistical analysis}

The influence of fuel models on the accuracy of simulated fire spread and behavior was assessed for all the case studies. An error matrix between observed and simulated fire perimeters was calculated to define the frequency of each case (presence/absence of burned areas). Sørensen's coefficient (SC; Legendre and Legendre, 1998) and Cohen's kappa coefficient $(K$; Congalton, 1991) were used as measures of the spatial accuracy of the extent of the simulated fire spread (Arca et al., 2007; Salis, 2008).

Sørensen's coefficient was used as indicator of the exclusive association between observed and simulated burned areas. SC values were calculated as follows:

$\mathrm{SC}=\frac{2 a}{2 a+b+c}$,

where $a$ is the number of cells coded as burned in both observed and simulated data (burned area agreement), $b$ is the number of cells coded as burned in the simulation and unburned in the observation (modeling overestimation) and $c$ is the number of cells coded as unburned in the simulation and burned in the observation (modeling underestimation; Arca et al., 2007).

Kappa statistics computes the frequency with which the simulated area agrees with the observed area, with an adjustment that takes into account agreement by chance (Filippi et al., 2014). $K$ values were calculated as follows:

$K=\frac{N \sum_{i=1}^{r} x_{i i}-\sum_{i=1}\left(x_{1+} x+1\right)}{N^{2}-\sum_{i=1}^{r}\left(x_{i+} x_{+i}\right)}$,

where $r$ is the number of rows in the matrix, $x_{i i}$ is the number of observations in row $i$ and column $i, x_{i+}$ and $x_{+i}$ are the 
Table 4. Statistical evaluation of FARSITE performances for different combinations of standard fuel models.

\begin{tabular}{|c|c|c|c|c|c|c|c|}
\hline $\begin{array}{c}\text { Case study } \\
\text { (observed fire size in ha) }\end{array}$ & $\begin{array}{c}\text { Simulation } \\
\text { number }\end{array}$ & Fuel model code & $\mathrm{SC}^{1}$ & $K^{2}$ & $\begin{array}{c}a^{3} \\
\text { (ha) }\end{array}$ & $\begin{array}{c}b^{4} \\
\text { (ha) }\end{array}$ & $\begin{array}{c}c^{5} \\
\text { (ha) }\end{array}$ \\
\hline \multirow{10}{*}{$\begin{array}{c}\text { Toshi } \\
\text { (34.18 ha) }\end{array}$} & I & (GR3, GS3, TU2, TU3) & 0.70 & 0.70 & 18.78 & 0.41 & 15.40 \\
\hline & II & (GR5, GS3, TU2, TU3) & 0.76 & 0.75 & 22.35 & 2.13 & 11.83 \\
\hline & III & (GR6, GS3, TU2, TU3) & 0.86 & 0.82 & 30.06 & 5.51 & 4.12 \\
\hline & IV & (GR6, GS4, TU2, TU3) & 0.83 & 0.81 & 28.14 & 5.78 & 6.04 \\
\hline & $\mathrm{V}$ & (FM3, GS3, TU2, TU3) & 0.82 & 0.79 & 27.08 & 4.53 & 7.10 \\
\hline & VI & (GR6, FM5, TU2, TU3) & 0.77 & 0.74 & 23.10 & 2.44 & 11.08 \\
\hline & VII & (GR6, GS3, FM10, TU3) & 0.71 & 0.69 & 20.45 & 2.73 & 13.73 \\
\hline & VIII & (GR6, GS3, TU2, FM10) & 0.73 & 0.71 & 22.18 & 4.51 & 12.00 \\
\hline & IX & (FM3, FM6, FM10) & 0.68 & 0.67 & 19.36 & 3.51 & 14.82 \\
\hline & $\mathrm{X}$ & (GR6, GS3, FM9, TU3) & 0.48 & 0.45 & 11.36 & 1.65 & 22.82 \\
\hline \multirow{5}{*}{$\begin{array}{l}\text { Malekroud } \\
(24.05 \mathrm{ha})\end{array}$} & I & (TL6, TL9) & 0.76 & 0.73 & 17.18 & 4.13 & 6.87 \\
\hline & II & (FM9, TL9) & 0.81 & 0.78 & 20.57 & 5.51 & 3.48 \\
\hline & III & (TL6, FM9) & 0.75 & 0.73 & 16.95 & 4.01 & 7.10 \\
\hline & IV & (TL6, FM10) & 0.73 & 0.71 & 15.84 & 3.48 & 8.21 \\
\hline & V & (FM9) & 0.79 & 0.75 & 19.45 & 5.60 & 4.60 \\
\hline \multirow{10}{*}{$\begin{array}{l}\text { YekeBermagh } \\
\text { (58.06 ha) }\end{array}$} & I & (GR4, GS1, GS2) & 0.26 & 0.22 & 58.06 & 326.48 & 0.00 \\
\hline & II & (GR7, GS1, GS2) & 0.24 & 0.20 & 58.06 & 358.90 & 0.00 \\
\hline & III & (FM3, GS1, GS2) & 0.41 & 0.38 & 58.06 & 165.91 & 0.00 \\
\hline & IV & (GR4, SH1, GS1) & 0.50 & 0.49 & 54.14 & 106.13 & 3.92 \\
\hline & V & (GR7, SH1, GS1) & 0.46 & 0.46 & 57.34 & 133.27 & 0.72 \\
\hline & VI & (GR4, SH1, SH2) & 0.69 & 0.68 & 46.84 & 30.75 & 11.22 \\
\hline & VII & (FM3, SH1, SH2) & 0.13 & 0.12 & 4.26 & 3.27 & 53.80 \\
\hline & VIII & (FM3, GS1, GS2) & 0.66 & 0.63 & 51.43 & 45.86 & 6.63 \\
\hline & IX & (FM3, FM5, FM6) & 0.67 & 0.66 & 50.14 & 41.67 & 7.92 \\
\hline & $X$ & (GR4, FM5, FM6) & 0.27 & 0.23 & 58.06 & 308.65 & 0.00 \\
\hline \multirow{7}{*}{$\begin{array}{l}\text { Gharangi } \\
\text { (10.04 ha) }\end{array}$} & $\mathbf{I}$ & (TU1, TU5, TL6, TL9) & 0.76 & 0.75 & 7.48 & 2.23 & 2.56 \\
\hline & II & (FM8, TU5, TL6, TL9) & 0.67 & 0.65 & 7.50 & 4.81 & 2.54 \\
\hline & III & (FM10, TU5, TL6, TL9) & 0.57 & 0.56 & 8.44 & 11.30 & 1.60 \\
\hline & IV & (TU1, FM10, TL6, TL9) & 0.72 & 0.69 & 6.93 & 2.18 & 3.11 \\
\hline & $\mathrm{V}$ & (TU1, TU5, FM9, TL9) & 0.71 & 0.68 & 6.87 & 2.24 & 3.17 \\
\hline & VI & (TU1, TU5, TL6, FM10) & 0.70 & 0.68 & 6.63 & 2.19 & 3.41 \\
\hline & VII & (FM8, FM9, FM10) & 0.70 & 0.68 & 6.79 & 2.54 & 3.25 \\
\hline
\end{tabular}

${ }^{1}$ Sørensen's coefficient value; ${ }^{2}$ Cohen's kappa coefficient value; ${ }^{3}$ burned area agreement between observed and modeled fire; ${ }^{4}$ simulation overestimation; ${ }^{5}$ simulation underestimation.

marginal totals of row $i$ and column $i$, respectively, and $N$ is the total number of observations. Both $K$ and SC coefficient values typically range between 0 and 1 , with values close to 1 indicating very high spatial agreement between simulated and observed fire perimeters (Arca et al., 2007).

Moreover, the "zonal statistics" tool of ArcGIS 10 was used to analyze and summarize the fire behavior data (ROS, FLI and FML) for each fuel model.

\section{Results}

\subsection{Fire simulation accuracy}

For all the case studies, the simulated burned areas were compared with the observed fire perimeters (Fig. 7, Tables 4 and 5). Overall, the statistics showed that FARSITE performances with the highest values for $K$ and SC coefficients, and therefore the scenarios that better replicate the observed fires, were obtained for all the case studies using the standard fuel models of Scott and Burgan (2005) with the exception of simulation II of Malekroud, where the standard fuel model (FM9) of Anderson (1982) showed the best accuracy in replicating the fire perimeter (Table 4).

In the Toshi fire event, the best results were obtained in simulation III (Fig. 7a, Table 4), where about 30.1 ha of the final fire area coincided with the observed fire size, while 4.1 and 5.5 ha were underestimated and overestimated, respectively, by FARSITE. As previously pointed out, the best values of SC and $K$ coefficients were obtained in simulation III ( $\mathrm{SC}=0.86, K=0.82$; Table 4$)$, whereas the other sim- 

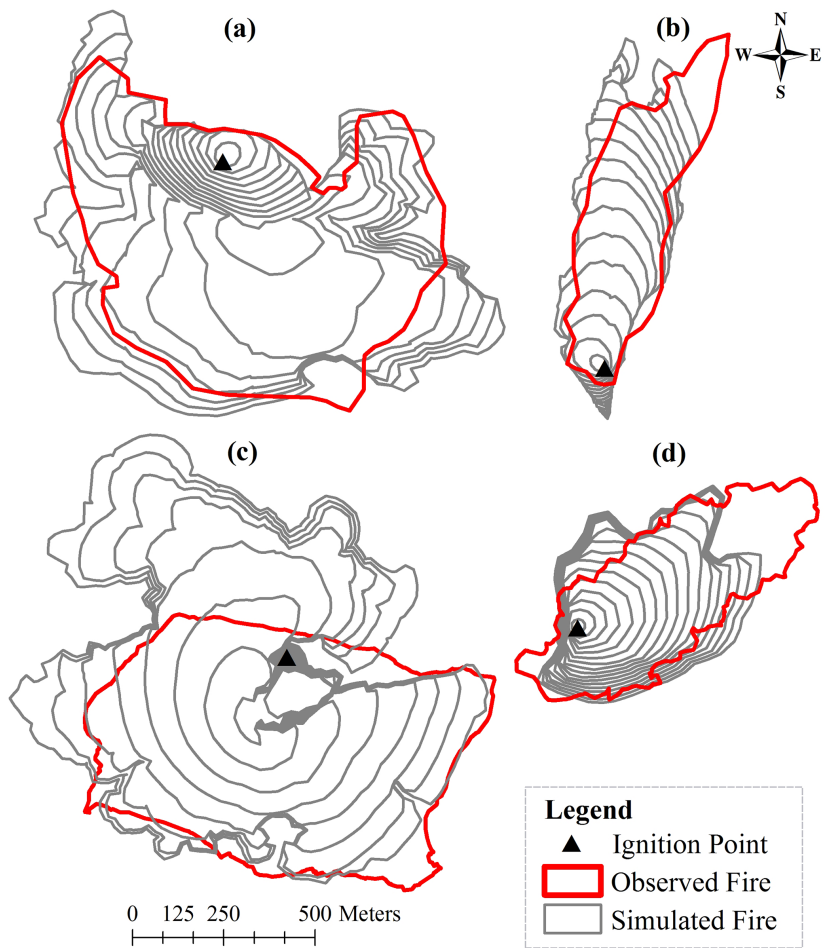

(d)

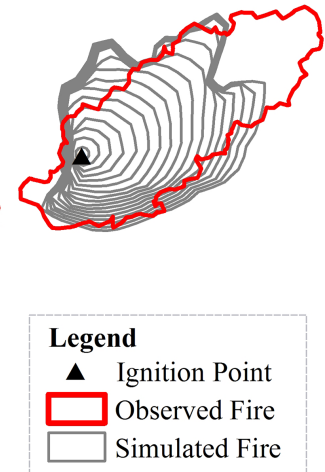

Figure 7. Fire spread perimeters (30 $\mathrm{m}$ interval) of the best FARSITE simulations (grey; III for Toshi, II for Malekroud, VI for YekeBermagh and I for Gharangi; Table 4) vs. observed fire perimeters (red): (a) Toshi, (b) Malekroud, (c) YekeBermagh, (d) Gharangi.

ulations presented lower accuracies, with $\mathrm{SC}$ values ranging from 0.48 to 0.83 and $K$ values from 0.45 to 0.81 . The best performance for Toshi wildfire, regarding the standard fuel models used, was obtained by the GR6 fuel model ( $\mathrm{SC}=0.92, K=0.87$; Table 5) for grasslands and the worst was observed for the TU3 fuel model $(\mathrm{SC}=0.75, K=0.73$; Table 5).

Simulation II of the Malekroud wildfire event (Fig. 7b, Table 4) replicated well the observed fire event, with an agreement between the observed and simulated fire area of about 20.6 ha and FARSITE underestimation and overestimation of 3.5 and 5.5 ha, respectively. The statistical analysis showed that the FM9 fuel model in simulation II provided the highest $\mathrm{SC}$ and $K$ values ( $\mathrm{SC}=0.85 ; K=0.82$; Table 5), while the other simulations using TL6 and FM10 fuel models gave SC values ranging from 0.73 and 0.79 and $K$ values ranging from 0.71 and 0.75 (Table 4). Focusing on single fuel models, the FM9 fuel model in Toshi case study provided the worst accuracy performance ( $\mathrm{SC}=0.48 ; K=0.45$; Table 4 ).

In simulation VI of the YekeBermagh case study (Fig. 7c, Table 4), the simulated fire area was characterized by an overestimation of 30.7 ha, mainly in the right back-flank of the fire spread. The agreement between the simulated and observed fire area was about 46.8 ha, while 11 ha of the fire area was underestimated (Table 4). The statistical test showed that in simulation VI, the GR4 fuel model provided the best SC and $K$ values ( $\mathrm{SC}=0.82, K=0.81$; Table 5), while the worst performances were provided by the FM3 fuel model in simulation VII ( $\mathrm{SC}=0.13, K=0.12$; Table 4) due to the wide underestimation of the area burned. The large underestimation was also confirmed for the FM5 and FM6 fuel models (Table 4).

In simulation I of the Gharangi wildfire event (Fig. 7d, Table 4), about 7.5 ha of the observed fire area was correctly simulated as burned area by FARSITE. The extent of the underestimation by the simulation was approximately 2.6 ha and the overestimation was 2.2 ha. The best agreement between simulated and observed fire was linked to TL9 fuel model ( $\mathrm{SC}=0.91 ; K=0.91$; Table 5 ), which was characterized by small overestimation and underestimation of the FARSITE perimeter.

Comparing the standard fuel models associated with the best simulations of FARSITE for each case study, the higher SC and $K$ values were obtained using the GR6 grassland model in simulation III of the Toshi fire $(\mathrm{SC}=0.92$; $K=0.87$; Table 5) and the TL9 timber model in simulation I of the Gharangi fire ( $\mathrm{SC}=0.91, K=0.91$; Table 5). The worst performances were provided by the model TU1 in simulation I of the Gharangi fire event $(\mathrm{SC}=0.47 ; K=0.45$; Table 5). On the whole, GR6, TU2, TU5 and TL9 fuel models replicated well the observed area burned ( $\mathrm{SC} \geq 0.90$ and $K \geq 0.82$; Table 5).

\subsection{Fuel models and fire behavior}

Due to differences in fuel models characteristics, topography and weather conditions, the simulations revealed diverse potential fire behavior. Surface fire rate of spread, fireline intensity and flame length were analyzed for each of the fuel models used in the four case studies (Fig. 8 and Table 5). The fire simulation outputs showed complex patterns that were generally related to the dominant fuel types and the topography.

Overall, the average wind speed conditions ranged between 14 and $23 \mathrm{~km} \mathrm{~h}^{-1}$ for the case studies presented (Table 2), and this is one of the main reasons why fires did not show high, fast-spreading output values $\left(0.53-2.61 \mathrm{~m} \mathrm{~min}^{-1}\right.$ average ROS; Table 5). The highest values of simulated ROS were observed with tall and dense grasslands and sparse shrubland vegetation in Toshi and YekeBermagh case studies (Table 5). The grasslands presented the fastest ROS, which varied from 0.05 to $10.84 \mathrm{~m} \mathrm{~min}^{-1}$ (Table 5) depending on topography; the shrublands showed a ROS ranging from 0.05 to $8.06 \mathrm{~m} \mathrm{~min}^{-1}$ (Table 5). The lowest ROS $\left(<1 \mathrm{~m} \mathrm{~min}^{-1}\right.$; Table 5) was obtained for the areas covered by mixed hardwood forest (TU1) and pure hardwood forest (TL6) in the Gharangi wildfire. In woodlands, modeled fire ROS was very slow due to the high fuel compactness and the relatively high moisture content; this explains the ROS values 2-3 times lower than in grassland fuel types (Table 5). 
Table 5. Statistical evaluation of the best FARSITE simulation (III for Toshi, II for Malekroud, VI for YekeBermagh and I for Gharangi; Table 4) for each case study. Mean values $( \pm \mathrm{SE})$ of the simulated ROS, FLI and FML are also reported.

\begin{tabular}{|c|c|c|c|c|c|c|c|c|c|c|c|}
\hline $\begin{array}{c}\text { Case study } \\
\text { (best simulation) }\end{array}$ & $\begin{array}{l}\text { Fuel } \\
\text { Model }\end{array}$ & $\mathrm{SC}^{1}$ & $\mathrm{~K}^{2}$ & $\begin{array}{l}a^{3} \\
\text { (ha) }\end{array}$ & $\begin{array}{c}b^{4} \\
\text { (ha) }\end{array}$ & $\begin{array}{l}c^{5} \\
\text { (ha) }\end{array}$ & $\begin{array}{l}\text { Observed } \\
\text { fire size (ha) }\end{array}$ & $\begin{array}{l}\text { Simulated } \\
\text { fire size (ha) }\end{array}$ & $\begin{array}{c}\operatorname{ROS}^{6} \\
\left(\mathrm{~m} \mathrm{~min}^{-1}\right)\end{array}$ & $\begin{array}{c}\mathrm{FLI}^{7} \\
\left(\mathrm{~kW} \mathrm{~m}^{-1}\right)\end{array}$ & $\begin{array}{l}\mathrm{FML}^{8} \\
(\mathrm{~m})\end{array}$ \\
\hline \multirow{5}{*}{$\begin{array}{l}\text { Toshi } \\
\text { (III) }\end{array}$} & GR6 & 0.92 & 0.87 & 12.87 & 2.11 & 0.27 & 13.14 & 14.98 & $3.94 \pm 2.49$ & $655.62 \pm 418.38$ & $1.44 \pm 0.46$ \\
\hline & GS3 & 0.87 & 0.85 & 3.98 & 0.43 & 0.70 & 4.68 & 4.41 & $1.20 \pm 0.38$ & $169.26 \pm 63.80$ & $0.80 \pm 0.16$ \\
\hline & TU2 & 0.90 & 0.82 & 6.28 & 0.07 & 1.35 & 7.63 & 6.35 & $0.58 \pm 0.31$ & $46.44 \pm 41.72$ & $0.42 \pm 0.14$ \\
\hline & TU3 & 0.75 & 0.73 & 6.93 & 2.90 & 1.80 & 8.73 & 9.83 & $1.61 \pm 1.55$ & $239.38 \pm 216.60$ & $0.88 \pm 0.42$ \\
\hline & Average & 0.86 & 0.82 & 30.06 & 5.51 & 4.12 & 34.18 & 35.57 & $2.27 \pm 2.23$ & $357.65 \pm 383.74$ & $1.01 \pm 0.53$ \\
\hline \multirow{3}{*}{$\begin{array}{l}\text { Malekroud } \\
\text { (II) }\end{array}$} & FM9 & 0.85 & 0.82 & 16.12 & 3.19 & 2.80 & 18.92 & 19.31 & $1.76 \pm 0.78$ & $126.35 \pm 56.01$ & $0.69 \pm 0.14$ \\
\hline & TL9 & 0.77 & 0.74 & 4.45 & 2.32 & 0.68 & 5.13 & 6.77 & $1.62 \pm 0.75$ & $262.96 \pm 155.09$ & $0.95 \pm 0.30$ \\
\hline & Average & 0.81 & 0.78 & 20.57 & 5.51 & 3.48 & 24.05 & 29.56 & $1.72 \pm 0.78$ & $160.63 \pm 108.19$ & $0.76 \pm 0.23$ \\
\hline \multirow{4}{*}{$\begin{array}{l}\text { YekeBermagh } \\
\text { (VI) }\end{array}$} & GR4 & 0.82 & 0.81 & 42.05 & 19.93 & 5.82 & 47.87 & 61.98 & $2.60 \pm 1.28$ & $341.26 \pm 255.52$ & $1.01 \pm 0.39$ \\
\hline & SH1 & 0.75 & 0.72 & 3.29 & 5.39 & 2.52 & 5.81 & 8.68 & $2.83 \pm 1.09$ & $266.89 \pm 113.11$ & $0.95 \pm 0.19$ \\
\hline & $\mathrm{SH} 2$ & 0.50 & 0.50 & 1.50 & 5.43 & 2.88 & 4.38 & 6.93 & $1.49 \pm 1.63$ & $248.52 \pm 234.96$ & $0.58 \pm 0.56$ \\
\hline & Average & 0.69 & 0.68 & 46.84 & 30.75 & 11.22 & 58.06 & 77.59 & $2.61 \pm 1.36$ & $277.86 \pm 416.89$ & $0.97 \pm 0.70$ \\
\hline \multirow{5}{*}{$\begin{array}{l}\text { Gharangi } \\
\text { (I) }\end{array}$} & TU1 & 0.47 & 0.45 & 0.90 & 0.82 & 2.18 & 3.08 & 1.72 & $0.32 \pm 0.29$ & $85.55 \pm 78.41$ & $0.45 \pm 0.36$ \\
\hline & TU5 & 0.90 & 0.85 & 3.52 & 0.52 & 0.30 & 3.82 & 4.04 & $0.67 \pm 0.24$ & $205.75 \pm 115.23$ & $0.86 \pm 0.22$ \\
\hline & TL6 & 0.77 & 0.77 & 0.95 & 0.49 & 0.08 & 1.03 & 1.44 & $0.23 \pm 0.04$ & $23.99 \pm 24.38$ & $0.32 \pm 0.09$ \\
\hline & TL9 & 0.91 & 0.91 & 2.11 & 0.40 & 0.00 & 2.11 & 2.51 & $0.63 \pm 0.19$ & $149.43 \pm 83.11$ & $0.74 \pm 0.20$ \\
\hline & Average & 0.76 & 0.75 & 7.48 & 2.23 & 2.56 & 10.04 & 9.71 & $0.53 \pm 0.28$ & $184.43 \pm 147.94$ & $0.76 \pm 0.37$ \\
\hline
\end{tabular}

1 Sørensen's coefficient value; ${ }^{2}$ Cohen's kappa coefficient value; ${ }^{3}$ burned area agreement; ${ }^{4}$ FARSITE overestimation; ${ }^{5}$ FARSITE underestimation; ${ }^{6}$ rate of spread; ${ }^{7}$ fireline intensity; 8 flame length.

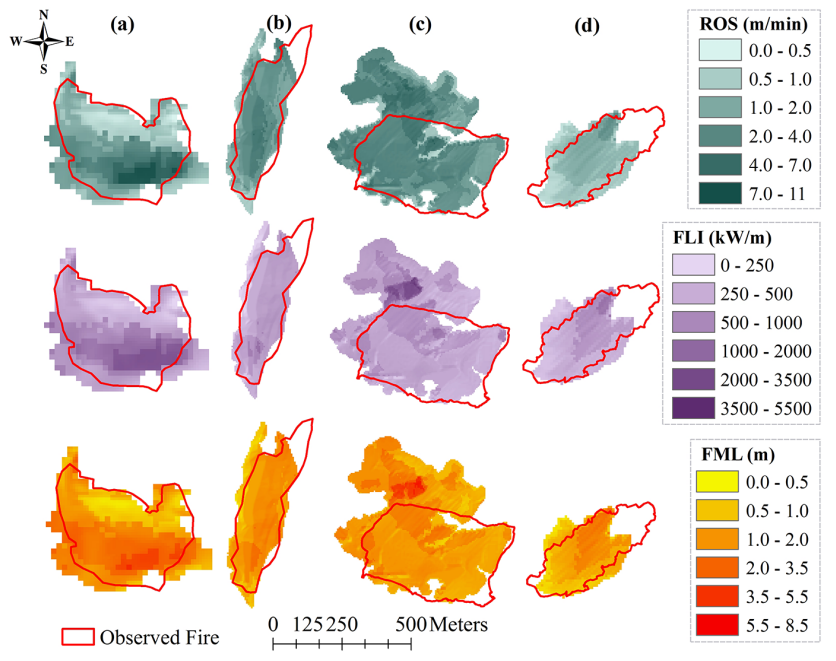

Figure 8. Simulated outputs of rate of spread (ROS), fireline intensity (FLI) and flame length (FML) for the most accurate simulation (III for Toshi, II for Malekroud, VI for YekeBermagh and I for Gharangi; Table 4): (a) Toshi, (b) Malekroud, (c) YekeBermagh, (d) Gharangi (see Table 4).

In addition to the ROS, relevant differences in terms of fire intensity (i.e., FLI and FML) were found between the different vegetation types. The high-fuel-load tall grass (GR6) presented the highest values (average FLI $>350 \mathrm{~kW} \mathrm{~m}^{-1}$ and FML > $1.4 \mathrm{~m}$; Table 5) and the compact litter and understory (TU1, TU2 and TL6) showed the lowest values (average
FLI $<100 \mathrm{~kW} \mathrm{~m}^{-1}$ and FML $<0.5 \mathrm{~m}$; Table 5). Nonetheless, high values were also locally associated with shrubby fuel models (SH1 and SH2; FLI $<250 \mathrm{~kW} \mathrm{~m}^{-1}$ and FML $>1 \mathrm{~m}$; Table 5) in YekeBermagh wildfire case study. The obtained fire intensity results in the different fuel models resembled observed flame lengths during the analyzed fire events.

\section{Discussion}

The wildfire spread depends on complex interactions among terrain, fuel types, weather conditions, fire suppression and the heat released by the fire environment (Viegas et al., 1998; Forthofer and Butler, 2007; Fernandes, 2009; Lee et al., 2010; Sharples et al., 2012; Cardil et al., 2013). The use of fire spread models can help in the understanding of potential fire behavior, improve logistics and decision-making and thereby improve awareness and safety of firefighters. Nevertheless, adoption and application of fire spread modeling in a given landscape should be preceded by a sound calibration process, as well as by validation efforts that demonstrate that the model outcomes describe well an event with acceptable errors (Stratton, 2006; Arca et al., 2007; Randall et al., 2007; Alexander and Cruz, 2013). In fact, modeling fires accurately is difficult due to a myriad of causes, including spatial heterogeneity in environmental factors and the variable effects of fire suppression over the range of fire sizes (Taylor et al., 2013). Additionally, calibration and validation of fire simulations in general are also made difficult by the multiple sources of error in data, which are confounded by 
the error of the model itself. These sources may include insufficient accuracy in spatial fuels information, the distance between the weather station locations to the area where the fire occurred, the mapping of fire perimeters or eventual errors from the user who runs the models (e.g., model parameter settings) (Finney et al., 2011). Many studies have shown that the use of both wind field data and appropriate custom fuel models is essential to obtain reasonable simulations of fire spread and behavior (Arca et al., 2007; Salis, 2008; Forthofer, 2007). In the current study, although the simulations with FARSITE were run at fine scale $(10 \mathrm{~m})$ using the most accurate available geospatial information for the study areas, the fire spread spatial output data accuracy might have been influenced since the fuels and topography input maps derived from $1: 25000$ scale land use land-cover and digital elevation models.

As highlighted by the current and other previous works (Stratton, 2009; Cochrane et al., 2012), FARSITE results in an accurate and reliable single fire event simulator able to replicate observed wildfires at high resolution $(20 \mathrm{~m}$ or finer resolutions). However, although FARSITE was also applied at landscape scale for several fire modeling and fire likelihood analysis (Bar Massada et al., 2011), other simulators like FlamMap and its command line Randig (also based on Rothermel's fire spread model; Finney et al., 2006) present some advantages with respect to FARSITE when working at large scales (thousands of hectares and square kilometers) and with a huge number of fire ignitions (several thousands for fire modeling) (Ager et al., 2007, 2010).

The goal of this paper was to assess the capabilities of FARSITE in replicating wildfire spread and behavior in northern Iran, where scientific studies and projects on fire behavior and spread are still limited. Plenty of studies on these topics have been carried out in the United States, southern Europe, other Mediterranean areas and local site-specific fuel models have been developed and widely employed in fire modeling (Finney, 1998, 2003; Finney et al., 2006; Scott and Burgan, 2005; Santoni and Balbi, 1998; Arca et al., 2006, 2007, 2009; Fernandes et al., 2006; Salis et al., 2010, 2013, 2014b). Although standard fuel models should not be applied uncritically to ecosystems outside of North America, this study showed that some standard fuel models accurately replicated the observed burned areas in our study areas.

Concerning the simulation accuracy, FARSITE overestimations were expected and observed for all case studies (especially in YekeBermagh) since suppression activities were not considered in the simulations. The good spatial agreement between the observed and simulated fire perimeters, as measured by SC and $K$ coefficients, resulted in values higher than 0.69 for SC and 0.68 for $K$ when considering all case studies and the most accurate FARSITE simulations. In more detail, the best FARSITE simulations ranged from 0.69 to 0.86 , in terms of SC, and from 0.68 to 0.82 , in terms of $K$ (Table 4).
Overall, the simulations performed using the standard fuel models by Scott and Burgan (2005) provided better results than the Anderson (1982) fuel models in replicating the observed fire area, with the exception of the Malekroud case study ( $\mathrm{SC}=0.81 ; K=0.78$; Table 4 ). Among the fuel models, the best match between observed and modeled area burned was observed in tall grasslands (GR6; Scott and Burgan, 2005; Table 5), although also other fuel models (TU2, TU5 and TL9) provided very high accuracy, with $\mathrm{SC} \geq 0.90$ and $K \geq 0.82$ (Table 5).

Simulation outputs of ROS, FLI and FML in a number of fuel models showed average values under suppression capabilities for fire extinction crews and equipment (Andrews et al., 2011; Table 5). As expected, and in agreement with the information provided by the Forest Brigades of the study areas, the highest spread rate and intensity values for the selected case studies were associated with high-fuel-load tall grass and shrubby fuel models. These results are in agreement with several studies conducted to estimate fire behavior variables, such as Arca et al. (2007) and White et al. (2013). The heading fire burning areas dominated by tall grass (GR6 and GR7) exhibited the highest rate of spread (ROS $>5 \mathrm{~m} \mathrm{~min}^{-1}$; Table 5) with moderate flame lengths (FML $<2.5 \mathrm{~m}$; Table 5), and such fire behavior presented the most important fire suppression difficulties due to a high rate of spread rather than the fireline intensity. The limitations in effectively controlling fire spread were locally amplified in certain areas where the terrain steepness was aligned with wind direction (e.g., Toshi wildfire, Fig. 8). On the other hand, fire extinction did not present relevant complications in crown fire activity lacking timber litter and timber understory fuel model areas, where the fuel moisture content, higher than in open areas, did not support a hazardous fire behavior.

\section{Conclusions}

There are relevant effects of the fuel models characteristics on simulated fire spread and behavior. FARSITE simulations performed for the fires events that affected northern Iranian forests highlighted different simulated fire perimeters, final size, rate of spread and intensity. Overall, in both study areas standard fuel models were able to represent local fuel types and characteristics, which were defined and mapped combining field sampling activities and $1: 25000$ scale land use land-cover maps. The best match between observed and simulated area burned was observed on grasslands fuel types.

Overall, fire modeling showed a high potential for estimating spatial variability in fire spread and behavior in the study areas. This work represents a first step in the application of fire spread modeling in northern Iran for wildfire risk monitoring and management. Quantifying potential fire behavior, exposure and risk in northern Iran represents a challenging point for researchers due to the limited availability of data 
about local fuels and fires, and further investigation and work of field sampling and mapping is needed. Furthermore, this work provides a useful methodology that can be replicated in the southern Caspian forests to characterize fire likelihood and intensity and increase local awareness of the risks posed by fires spreading in such forest ecosystems.

Nevertheless, there were some limitations in the present study (i.e., the insufficiency or lack of custom fuel models, high-resolution wind field data, the lack of accurate information on observed fire spread and medium-scale featurederived landscape input maps) that may have affected the accuracy of the results. Further efforts in future studies should be carried out to simulate locally the spatial variation of wind speed and direction, improve the standard fuel model assignments to the different vegetation types and develop a more precise fuel model guide for northern Iran with custom models through field samplings on local vegetation complexes. 


\section{Appendix A}

Table A1. Data used for calculating initial dead fuel moisture content (FMC) for the wildfire case studies. The FMC values were calculated according to the method proposed by Rothermel (1983).

\begin{tabular}{|c|c|c|c|c|c|}
\hline \multicolumn{2}{|r|}{ Variable } & \multicolumn{4}{|c|}{ Wildfire } \\
\hline & & Toshi & Malekroud & YekeBermagh & Gharangi \\
\hline 1 & Ambient temperature & 28 & 16 & 24 & 10 \\
\hline 2 & Relative humidity & 50 & 58 & 21 & 49 \\
\hline 3 & Reference number for fuel moisture (Rothermel, 1983, p. 17) & 8 & 8 & 4 & 8 \\
\hline 4 & Month & August & December & July & March \\
\hline 5 & Table to be used (Rothermel, 1983, p. 18) & $\mathrm{C}$ & $\mathrm{D}$ & B & $\mathrm{C}$ \\
\hline 6 & exposed* or shaded & exposed & exposed & exposed & shaded \\
\hline 7 & Time of day & 16 & 17 & 11 & 14 \\
\hline 8 & Elevation change from weather station & above & above & $\mathrm{L}$ & $\mathrm{L}$ \\
\hline 9 & Aspect & south & south & south & south \\
\hline 10 & Slope $(0-30 \%$ or $>30 \%)$ & $>30 \%$ & $0-30 \%$ & $0-30 \%$ & $0-30 \%$ \\
\hline 11 & Fuel moisture correction $\%$ - using month table & 2 & 5 & 0 & 4 \\
\hline 12 & Initial fine dead fuel moisture (line $3+$ line 11 ) & 10 & 13 & 4 & 12 \\
\hline
\end{tabular}

* Less than $50 \%$ shading of surface fuels. 
Acknowledgements. We would like to thank the Iranian Forests, Range and Watershed Management Organization and the Iranian Department of Environment for authorizations and logistic support during the field work. We wish to acknowledge the unrelenting help of the directors of the Department of Natural Resources of Siahkal and the Golestan National Park, as well as park rangers and firefighters. The authors also acknowledge financial support from the Natural Sciences and Engineering Research Council of Canada (NSERC). The activity of M. Salis was supported by the project "Modeling approach to evaluate fire risk and mitigation planning actions" (P.O.R. SARDEGNA F.S.E. 2007-2013, Asse IV Capitale Umano, Linea di Attività 1.3.1).

Edited by: R. Lasaponara

Reviewed by: three anonymous referees

\section{References}

Adab, H., Kanniah, K. D., and Solaimani, K.: Modeling forest fire risk in the northeast of Iran using remote sensing and GIS techniques, Nat. Hazards, 65, 1723-1743, doi:10.1007/s11069-0120450-8, 2013.

Adel, M. N., Pourbabaei, H., Omidi, A., and Pothier, D.: Long-term effect of fire on herbaceous species diversity in oriental beech (Fagus orientalis Lipsky) forests in Northern Iran, Forestry Studies in China, 14, 260-267, 2012.

Ager, A. A., Finney, M. A., Kerns, B. K., and Maffei, H.: Modeling wildfire risk to northern spotted owl (Strix occidentalis caurina) habitat in Central Oregon, USA, Forest Ecol. Manag., 246, 45-5, doi:10.1016/J.FORECO.2007.03.070, 2007.

Ager, A. A., Vaillant, N. M., and Finney, M. A.: A comparison of landscape fuel treatment strategies to mitigate wildland fire risk in the urban interface and preserve old forest structure, Forest Ecol. Manag., 259, 1556-1570, doi:10.1016/J.FORECO.2010.01.032, 2010.

Ager, A. A., Vaillant, N., and Finney, M. A.: Integrating Fire Behavior Models and Geospatial Analysis for Wildland Fire Risk Assessment and Fuel Management Planning, J. Combust., 2011, 19 pp., doi:10.1155/2011/572452, 2011.

Ager, A. A., Vaillant, N. M., Finney, M. A., and Preisler, H. K.: Analyzing wildfire exposure and source sink relationships on a fire prone forest landscape, Forest Ecol. Manag., 267, 271-283, 2012.

Ager, A. A., Preisler, H., Arca, B., Spano, D., and Salis, M.: Wildfire risk estimation in the Mediterranean area, Environmetrics, 25, 384-396, doi:10.1002/env.2269, 2014a.

Ager, A. A., Buonopane, M., Reger, A., and Finney, M. A.: Wildfire exposure analysis on the national forests in the Pacific Northwest, USA, Risk Anal., 33, 1000-1020, 2014b.

Akhani, H.: Plant biodiversity of Golestan National Park, Iran, Stapfia, 53, 1-411, 1998.

Akhani, H. and Ziegler, H.: Photosynthetic pathways and habitats of grasses in Golestan National Park (NE Iran), with an emphasis on the C4-grass dominated rock communities, Phytocoenologia, 32, 455-501, 2002.

Akhani, H., Djamali, M., Ghorbanalizadeh, A., and Ramezani, E.: Plant biodiversity of Hyrcanian relict forests, $N$ Iran: an overview of the flora, vegetation, palaeoecology and conservation, Pak. J. Bot., 42, 231-258, 2010.

Alexander, M. E. and Cruz, M. G.: Are the applications of wildland fire behaviour models getting ahead of their evaluation again?, Environ. Modell. Softw., 41, 65-71, 2013.

Anderson, H. E.: Aids to determining fuel models for estimating fire behaviour, General Technical Report INT-GTR-122, USDA Forest Service, Intermountain Forest and Range Experiment Station, US Department of Agriculture, Ogden, Utah, USA, 1982.

Andrews, P. L., Heinsch, F. A., and Schelvan, L.: How to generate and interpret fire characteristics charts for surface and crown fire behavior, General Technical Report RMRS-GTR-253, USDA Forest Service, Rocky Mountain Research Station, Fort Collins, CO, USA, 2011.

Arca, B., Duce, P., Pellizzaro, G., Laconi, M., Salis, M., and Spano, D.: Evaluation of FARSITE simulator in Mediterranean shrubland, Forest Ecol. Manag., 234, S110, 2006.

Arca, B., Duce, P., Laconi, M., Pellizzaro, G., Salis, M., and Spano, D.: Evaluation of FARSITE simulator in Mediterranean maquis, Int. J. Wildland Fire, 16, 563-572, 2007.

Arca, B., Bacciu, V., Pellizzaro, G., Salis, M., Ventura, A., Duce, P., Spano, D., and Brundu, G.: Fuel model mapping by IKONOS imagery to support spatially explicit fire simulators, in: 7th International Workshop on Advances in Remote Sensing and GIS Applications in Forest Fire Management towards an Operational Use of Remote Sensing in Forest Fire Management, Matera, Italy, 25 September, 4 pp., 2009.

Balbi, J. H., Morandini, F., Silvani, X., Filippi, J. B., and Rinieri, F. A.: Physical model for wildland fires, Combust. Flame, 156, 2217-2230, 2009.

Banj Shafiei, A., Akbarinia, M., Jalali, G., and Hosseini, M.: Forest fire effects in beech dominated mountain forest of Iran, Forest Ecol. Manag., 259, 2191-2196, 2010.

Bar Massada, A. B., Syphard, A. D., Hawbaker, T. J., Stewart, S. I., and Radeloff, V. C.: Effects of ignition location models on the burn patterns of simulated wild fires, Environ. Modell. Softw., 26, 583-592, 2011.

Bird, B. R., Bird, D. W., Codding, B. F., Parker, C. H., and Jones, J. H.: The "fire stick farming" hypothesis: Australian aboriginal foraging strategies, biodiversity, and anthropogenic fire mosaics, P. Natl. Acad. Sci. USA, 105, 14796-14801, 2008.

Boboulos, M., Purvis, M. R. I., and Penchev, S. I.: Fuel model development for the Greek East-Mediterranean forest litter layer, Fire Mater., 37, 597-611, doi:10.1002/fam.2159, 2013.

Bracmort, K.: Wildfire damages to homes and resources: understanding causes and reducing losses, Congressional Research Service (CRS), Washington, DC, USA, 27 pp., 2012.

Byram, G. M.: Combustion of forest fuels, In: Forest Fire Control and Use, edited by: Davis, K. P., McGraw-Hill Book Company, New York, USA, 61-89, 1959.

Cai, L., He, H. S., Wu, Z., Lewis, B. L., and Liang, Y.: Development of Standard Fuel Models in Boreal Forests of Northeast China through Calibration and Validation, PLoS ONE, 9, e94043, doi:10.1371/journal.pone.0094043, 2014.

Cardil, A., Molina, D. M., Ramirez, J., and Vega-García, C.: Trends in adverse weather patterns and large wildland fires in Aragón (NE Spain) from 1978 to 2010, Nat. Hazards Earth Syst. Sci., 13, 1393-1399, doi:10.5194/nhess-13-1393-2013, 2013. 
Carvalho, J. P., Carola. M., and Tomé. J. A. B.: Forest fire modeling using rule-base fuzzy cognitive maps and voronoi based Cellular Automata, in: Annual Meeting of the North American Fuzzy Information Processing Society NAFIPS 2006, Montreal, QC, Canada, 3-6 June 2006, 217-222, 2006.

Chuvieco, E., Yebra, M., Jurdao, S., Aguado, I., Salas, F. J., García, M., Nieto, H., De Santis, A., Cocero, D., Ria no, D., Martínez, S., Zapico, E., Recondo, C., Martínez-Vega, J., Martín, M. P., Riva, J., Pérez, F., and Rodríguez-Silva, F.: Field fuel moisture measurements on Spanish study sites, Department of Geography, University of Alcalá, Spain. Version 1, available at: http://www.geogra.uah.es/emilio/FMC_UAH.html (last access: September 2014), 2011.

Cochrane, M. A., Moran, C. J., Wimberly, M. C., Baer, A. D., Finney, M. A., Beckendorf, K. L., Eidenshink, J., and Zhu, Z.: Estimation of wildfire size and risk changes due to fuels treatments, Int. J. Wildland Fire, 21, 357-367, 2012.

Coleman, J. R. and Sullivan, A. L.: A real-time computer application for the prediction of fire spread across the Australian landscape, Simulation, 67, 230-240, 1996.

Congalton, R. G.: A review of assessing the accuracy of classifications of remotely sensed data, Remote Sens. Environ., 37, 35-46, doi:10.1016/0034-4257(91)90048-B, 1991.

Cruz, M. G. and Fernandes, P. M.: Development of fuel models for fire behavior prediction in maritime pine (Pinus pinaster Ait.) stands, Int. J. Wildland Fire, 17, 194-204, 2008.

Dimitrakopoulos, A. P.: Mediterranean fuel models and potential fire behavior in Greece, Int. J. Wildland Fire, 11, 127-130, 2002.

Djamali, M., de Beaulieu, J. L., Campagne, P., Andrieu-Ponel, V., Ponel, P., Leroy, S. A. G., and Akhani, H.: Modern pollen rainvegetation relationships along a forest-steppe transect in the Golestan National Park, NE Iran, Rev. Palaeobot. Palyno., 153, 272-281, 2009.

Duguy, B., Alloza, J. A., Röder, A., Vallejo, R., Pastor, F.: Modeling the effects of landscape fuel treatments on fire growth and behaviour in a Mediterranean landscape (eastern Spain), Int. J. Wildland Fire, 16, 619-632, 2007.

Fernandes, P. M.: Examining fuel treatment longevity through experimental and simulated surface fire behaviour: a maritime pine case study, Can. J. Forest Res., 39, 2529-2535, 2009.

Fernandes, P. M., Luz, L., Loureiro, C., Ferreira-Godinho, P., and Botelho, H.: Fuel modelling and fire hazard assessment based on data from the Portuguese National Forest Inventory, Forest Ecol. Manag., 234, S229, doi:10.1016/j.foreco.2006.08.256, 2006.

Filippi, J. B., Mallet, V., and Nader, B.: Evaluation of forest fire models on a large observation database, Nat. Hazards Earth Syst. Sci., 14, 3077-3091, doi:10.5194/nhess-14-3077-2014, 2014.

Finney, M. A.: FARSITE: fire area simulator - model development and evaluation, Res. Pap. RMRS-RP-4, US Department of Agriculture, Forest Service, Rocky Mountain Research Station, Ogden, UT, USA, 1998.

Finney, M. A.: Design of regular landscape fuel treatment patterns for modifying fire growth and behavior. Forest Sci., 47, 219-228, 2001.

Finney, M. A.: Calculation of fire spread rates across random landscapes, Int. J. Wildland Fire, 12, 167-174, 2003.

Finney, M. A. and Ryan, K. C.: Use of the FARSITE fire growth model for fire prediction in the US national parks, in: Inter- national Emergency Management and Engineering Conference, Nice, France, 9-12 May 1995, 183-189, 1995.

Finney, M. A., Seli, R.C., McHugh, C. W., Ager, A.A., Bahro, B., and Agee, J.K.: Simulation of long-term landscape-level fuel treatment effects on large wildfires, in: Fuels Management-How to Measure Success: Conference Proceedings, Portland, OR, USA, 28-30 March 2006, 125-148, 2006.

Finney, M. A., Grenfell, I. C., McHugh, C. W., Seli, R. C., Trethewey, D., Stratton, R. D., and Brittain, S.: A method for ensemble wildland fire simulation, Environ. Modell. Assess., 16, 153-167, 2011.

Forthofer, J. M.: Modeling Wind in Complex Terrain for Use in Fire Spread Prediction, Master's Thesis, Colorado State University, Fort Collins, Colorado, USA, 2007.

Forthofer, J. and Butler, B.: Differences in simulated fire spread over Askervein Hill using two advanced wind models and a traditional uniform wind field, USDA Forest Service Proceedings RMRS-P46, US Department of Agriculture, Forest Service, Rocky Mountain Research Station, 2007.

Glasa, J. and Halada, L.: A note on mathematical modelling of elliptical fire propagation, Comput. Inform., 30, 1303-1319, 2011.

Gu, F., Hu, X., and Ntaimo, L.: Towards validation of DEVS-FIRE wildfire simulation model, in: Proceedings of the 2008 Spring Simulation Multiconference, Ottawa, Canada, 14-17 April 2008, 355-361, 2008.

Hardison, T.: Application of Remote Sensing and GIS to modelling fire for vegetative restoration in Northern Arizona, MSc Thesis (Biology), University of North Texas, USA, 57 pp., 2003.

Keeley, J. E. and Fotheringham, C. J.: The historical role of fire in California shrublands, Conserv. Biol., 15, 1536-1548, 2001.

LaCroix, J. J., Ryu, S. R., Zheng, D., and Chen, J.: Simulating fire spread with landscape management scenarios, For. Sci., 52, 522 529, 2006.

Lee, H., Limb, S., and Paikc, H.: An assessment of fire-damaged forest using spatial analysis techniques, J. Spat. Sci., 55, 289301, 2010.

Leestmans, R.: Le refuge caspien et son importance en biogéographie, Linneana Belgica, 10, 97-102, 2005 (in French).

Legendre, P. and Legendre, L.: Numerical Ecology, 2nd Edn., Elsevier, Amsterdam, the Netherlands, 1998.

Leroy, A. G. S. and Arpe, K.: Glacial refugia for summer-green trees in Europe and south-west Asia as proposed by ECHAM3 time-slice atmospheric model simulations, J. Biogeogr., 34, 2115-2128, 2007.

Mallinis, G., Mitsopoulos, I. D., Dimitrakopoulos, A. P., Gitas, I. Z., and Karteris, M.: Local-scale fuel-type mapping and fire behaviorprediction by employing high-resolutionsatellite imagery, IEEE J. Sel. Top. Appl., 1, 230-239, 2008.

Marshall, P. L., Davis, G., and LeMay, V. M.: Using line intersect sampling for coarse woody debris, tecnical report TR-003, Research Section, Vancouver Forest Region, British Columbia Ministry of Forests, Canada, 37 pp., 2000.

Marshall, P. L., Davis, G., and Taylor, S.: Using line intersect sampling for coarse woody debris: practitioner's questions addressed, Note EN-012, Vancouver Forest Region Extension, Ministry of Forests, Canada, 10 pp., 2003.

Martinez, J., Vega-Garcia, C., and Chuvieco, E.: Human-caused wildfire risk rating for prevention planning in Spain, J. Environ. Manage., 90, 1241-1252, 2009. 
Marvi Mohadjer, M.: Silviculture, University of Tehran Press, Tehran, Iran, 387 pp., 2005 (in Persian).

Mendes-Lopes, J. and Aguas, C.: SPREAD - Un programa de Automatos Celulares para Propagaçao de Fogos Florestais, Silva Lusitana, 8, 3-47, 2000.

Mirdeylami, T., Shataee, S., and Kavousi, M. R.: Forest fire risk zone mapping in the Golestan national park using weighted linear combination (WLC) method, Iranian Journal of Forest, 5, 377-390, 2014 (in Persian).

Molina, D. M. and Castellnou, M.: Wildland fuel management in Catalonia (NE Spain), in: Actes de la 1ère Conférence Internationale sur les Stratégies de Prévention des Incendies dans les Forêts d'Europe du Sud, Bordeaux, France, Préventique, Bordeaux, 31 January-2 February 2002, 95-102, 2002.

Opperman, T., Gould, J., Finney, M., and Tymstra, C.: Applying fire spread simulators in New Zealand and Australia: results from an international seminar, in: Fuels Management-How to Measure Success: Conference Proceedings, Portland, OR, USA, 28-30 March 2006, 201-212, 2006.

Pastor, E., Zarate, L., Planas, E., and Arnaldos, J.: Mathematical models and calculation systems for the study of wildland fire behavior, Prog. Energy Combust. Sci., 29, 139-153, 2003.

Pausas, J. G., Llovet, J., Rodrigo, A., and Vallejo, R.: Are wildfires a disaster in the Mediterranean basin? - A review, Int. J. Wildland Fire, 17, 713-723, 2008.

Perry, G. L. W.: Current approaches to modelling the spread of wildland fire: a review, Prog. Phys. Geogr., 22, 222-245, 1998.

Pettinari, M. L., Ottmar, R. D., Prichard, S. J., Andreu, A. G., and Chuvieco, E.: Development and mapping of fuel characteristics and associated fire potentials for South America, Int. J. Wildland Fire, 23, 643-654, 2014.

Pierce, D., McDaniel, S., Wasser, M., Ainsworth, A., Litton, C. M., Giardina, C. P., and Cordell, S.: Using a prescribed fire to test customand standard fuel models for fire behavior prediction in a non-native, grass-invaded tropical dry shrubland, Appl. Veg. Sci., 17, 700-710, doi:10.1111/avsc.12111, 2014.

Prometheus Project Steering Committee: Development and Application of a Wildland Fire Growth Model. Proposal to Foothills Model Forest, Canadian Forest Service, 28 pp., 1999.

Randall, D. A., Wood, R. A., Bony, S., Colman, R., Fichefet, T., Fyfe, J., Kattsov, V., Pitman, A., Shukla, J., Srinivasan, J., Stouffer, R. J, Sumi, A., and Taylor, K. E.: Climate models and their evaluation, in: Climate Change 2007: The Physical Science Basis. Contribution of Working Group I to the Fourth Assessment Report of the Intergovernmental Panel on Climate Change, edited by: Solomon, S., Qin, D., Manning, M., Chen, Z., Marquis, M., Averyt, K. B., Tignor, M., and Miller, H. L., Cambridge University Press, Cambridge, UK, 589-662, 2007.

Rodríguez y Silva, F. and Molina-Martínez, J. R.: Modelling Mediterranean forest fuels by integrating field data and mapping tools, Eur. J. For. Res., 131, 571-582, doi:10.1007/s10342-0110532-2, 2011.

Romero-Calcerrada, R., Novillo, C., Millington, J. D. A., and Gomez-Jimenez, I.: GIS analysis of spatial patterns of humancaused wildfire ignition risk in the SW of Madrid (Central Spain), Landscape Ecol., 23, 341-354, 2008.

Rothermel, R. C.: A Mathematical Model for Predicting Fire Spread in Wildland Fuels, USDA Forest Service Research Paper, INT-
115, Intermountain Forest and Range Experiment Station, Ogden, UT, 1972.

Rothermel, R. C.: How to Predict the Spread and Intensity of Forest and Range Fires, National Wildlife Coordinating Group, Boise, ID, 1983

Ryu, S. R., Chen, J., Zheng, D., and LaCroix, J. J.: Relating surface fire spread to landscape structure: an application of FARSITE in a managed forest landscape, Landscape Urban Plan., 83, 275283, 2007.

Sağlam, B., Bilgili, E., Küçük, O., and Durmaz, B. D.: Fire behavior in Mediterranean shrub species (Maquis), Afr. J. Biotechnol., 7, 4122-4129, 2008.

Salis, M.: Fire Behavior Simulation in Mediterranean Maquis Using FARSITE (Fire Area Simulator), Ph.D. Thesis, Università degli Studi di Sassari, Dipartimento di Economia e Sistemi Arborei, Sassari, Italy, 130 pp., 2008.

Salis, M., Arca, B., Bacciu, V., Spano, D., Duce, P., Santoni, P., Ager, A., and Finney, M.: Application of wildfire spread and behavior models to assess fire probability and severity in the Mediterranean region, EGU General Assembly, Vienna, Austria, 2-7 May 2010, Geophysical Research Abstracts, 12, EGU201012991, 2010

Salis, M., Ager, A. A., Arca, B., Finney, M. A., Bacciu, V., Duce, P., and Spano, D.: Assessing exposure of human and ecological values to wildfire in Sardinia, Italy, Int. J. Wildland Fire, 22, 549565, 2013.

Salis, M., Ager, A. A., Arca, B., Finney, M. A., Alcasena, F., Bacciu, V., Duce, P., Lozano, O. M., and Spano, D.: Analyzing wildfire exposure on Sardinia, Italy, EGU General Assembly, Vienna, Austria, 27 April-2 May 2014, Geophysical Research Abstracts, 16, EGU2014-11596, 2014a.

Salis, M., Ager, A. A., Finney, M. A., Arca, B., and Spano, D.: Analyzing spatiotemporal changes in wildfire regime and exposure across a Mediterranean fire-prone area, Nat. Hazards, 71, 1389_ $1418,2014 b$

Salis, M., Ager, A. A., Alcasena, F., Arca, B., Finney, M. A., Pellizzaro, G., and Spano, D.: Analyzing seasonal patterns of wildfire likelihood and intensity in Sardinia, Italy, Environ. Monit. Assess., 187, 1-20, doi:10.1007/s10661-014-4175-x, 2015.

Santoni, P. A. and Balbi, J. H.: Modelling of two dimensional flame spread across a sloping fuel bed, Fire Safety J., 31, 201-225, 1998.

Santoni, P. A., Filippi, J. B., Balbi, J. H., and Bosseur, F.: Wildland fire behaviour case studies and fuel models for landscape-scale fire modeling, J. Combust., 2011, 613424, doi:10.1155/2011/613424, 2011.

Sarkargar Ardakani, A.: Analysis of radiometric-spatial characteristics of fire and its Application in identification and separation by remote sensing data, Ph.D. thesis, Faculty of Engineering, KhajeNasir-Toosi University, Tehran, Iran, 290 pp., 2007 (in Persian).

Schmidt, D. A., Taylor, A. H., and Skinner, C. N.: The influence of fuels treatment and landscape arrangement on simulated fire behavior, Southern Cascade range, California, Forest Ecol. Manag., 255, 3170-3184, 2008.

Scott, J. H. and Burgan, R.: Standard Fire Behavior Fuel Models: a Comprehensive Set for Use with Rothermel's Surface Fire Spread Model, RMRS-GTR-153, USDA Forest Service, Rocky Mountain Research Station, Fort Collins, CO, USA, 2005. 
Sharples, J. J., McRae, R. H. D., and Wilkes, S. R.: Wind-terrain effects on the propagation of wildfires in rugged terrain: fire channelling, Int. J. Wildland Fire, 21, 282-296, 2012.

Siadati, S., Moradi, H., Attari, F., Etemad, V., Hamzeh'ee, B., and Naqinezhad, A.: Botanical diversity of Hyrcanian forests; a case study of a transect in the Kheyrud protected lowland mountain forests in Northern Iran, Phytotaxa, 7, 1-18, 2010.

Stephens, S. L.: Evaluation of the effects of silvicultural fuels treatments on potential fire behaviour in Sierra Nevada mixed-conifer stands, Forest Ecol. Manag., 105, 21-35, doi:10.1016/S03781127(97)00293-4, 1998.

Stratton, R. D.: Assessing the effectiveness of landscape fuel treatments on fire growth and behavior, J. Forest., 102, 32-40, 2004.

Stratton, R. D.: Guidance on Spatial Wildland Fire Analysis: Models, Tools, and Techniques, Gen. Tech. Rep. RMRS-GTR-183, US Department of Agriculture, Forest Service, Rocky Mountain Research Station, Fort Collins, CO, USA, 15 pp., 2006.

Stratton, R. D.: Guidebook on LANDFIRE fuels data acquisition, critique, modification, maintenance, and model calibration, Gen. Techn. Rep. RMRS-GTR-220, US Department of Agriculture, Forest Service, Rocky Mountain Research Station, Fort Collins, CO, USA, 54 pp., 2009.

Syphard, A. D., Radeloff, V. C., Keeley, J. E., Hawbaker, T. J., Clayton, M. K., Stewart, S. I., and Hammerm, R. B.: Human influence on California fire regimes, Ecol. Appl., 17, 1388-1402, 2007.
Sullivan, A.: Wildland surface fire spread modelling, 1990-2007. 2: Empirical and quasiempirical models, Int. J. Wildland Fire, 18, 369-386, 2009.

Taylor, S. W., Woolford, D. G., Dean, C. B., and Martell, D. L.: Wildfire prediction to inform firemanagement: statistical science shallenges, Stat Sci., 28, 586-615, 2013.

Viegas, D. X., Ribeiro, P. R., and Maricato, L.: An empirical model for the spread of a fireline inclined in relation to the slope gradient or to wind direction, in: Proceeding of the Third International Conference on Forest Fire Research, University of Coimbra, Coimbra, Portugal, 325-342, 1998.

White, B. L. A., Ribeiro, A. S., Reibeiro, G. T., and Souza, R. M.: Building fuel models and simulating their surface fire behavior in the "Serra De Itabaiana" National Park, Sergipe, Brazil, FLORESTA, Curitiba, PR, 43, 27-38, 2013.

Zarekar, A., Kazemi Zamani, B., Ghorbani, S., Ashegh Moalla, M., and Jafari, H.: Mapping spatial distribution of forest fire using MCDM and GIS, case study: three forest zones in Guilan province, Iranian Journal of Forest and Poplar Research, 21, 218 230, 2013 (in Persian). 